\title{
北海道十勝平野地域の石汕地質学的研究
}

\author{
鬼潒貞*
}

(四和 37 年 5 月 30 日受理)

\section{Studies on the Petroleum Geology of the Tokachi Region in Hokkaido}

By

\author{
Tadashi ONITSUKA
}

\begin{abstract}
In the Tokathi region, situdted in eastern part of Hokkaido, some oil seeps are found from early days. However, the oil exploration surveys started in 1956, and the well drilling are not carried out up to 1961 .

In this paper, the compiling studies of the results of surface geological surveys, seismic surveys, and gravitational surveys are described, and the possibility of oil production at the south-eastern part of Tokachi region is considered.

Results of the studies are as follows;

(a) The standard stratigaphic order of oil-bearing Neogene system in the Tokachi region is amost established, and the correlation to the Tertiary Formations of oil producing area in central Hokkaido is become clear.

(b) The shape and property of the sedimentary basin are nearly cleared up.

(c) The main source rock of pztroleum may be the Taki and equivalent Toberi, Kawakami Group, and their wide development is expected in this region. The reservoir rocks are contained in these groups, and at the lowest course-grained parts of the overlied Tokachi Group.

(d) The author presumes that the oil accumlations at the Sarubetsu anticline and some anticlinal structures of its western side are the most hopeful zone.
\end{abstract}

\section{I. 緒言}

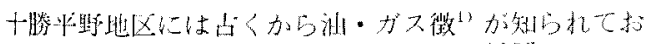

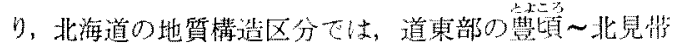
に属して独自の地史を椡った地蔽てある。

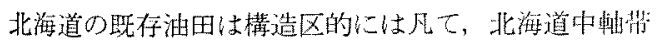
に属し，さまた寒日本油田の所讄グリーンタフ地带とは 異った地贡を持っている。

この様に構造区か買っても油田は「ての案件さえすれ

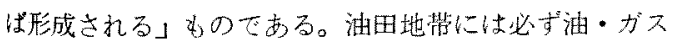
徽代任しているが，十勝平理地域の油田成立の可能性

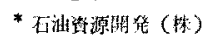

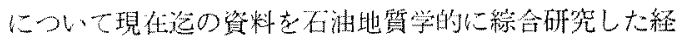

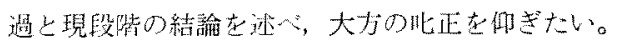

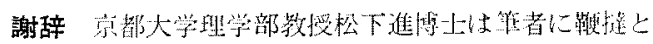

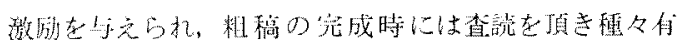

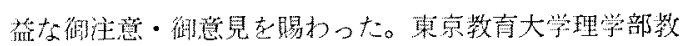

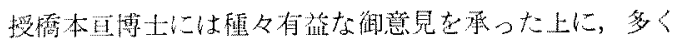

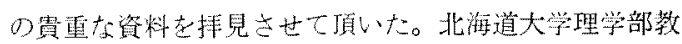

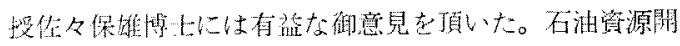

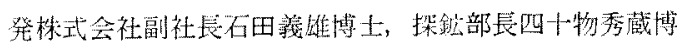

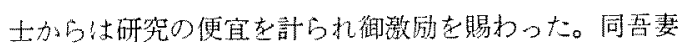

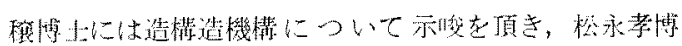

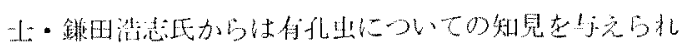

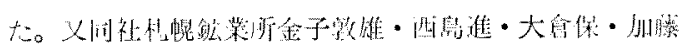




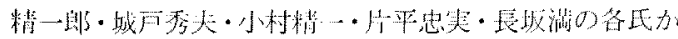

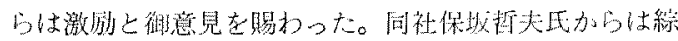

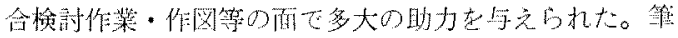

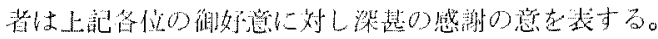

\section{II. 研究の範囲}

\section{A. 研究地域と調查の歴史}

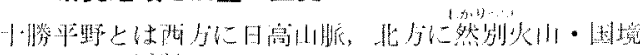

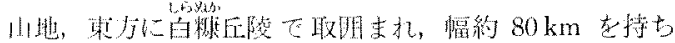

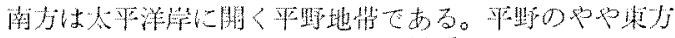

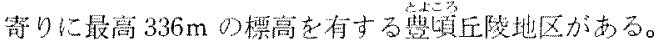

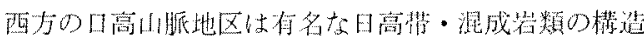

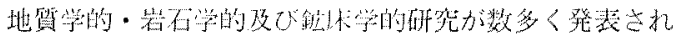

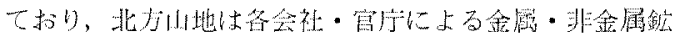

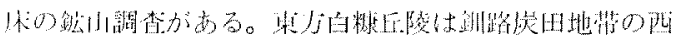

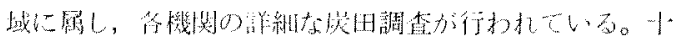

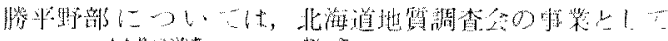

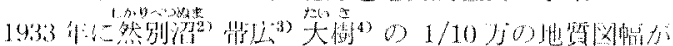

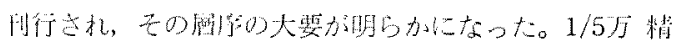

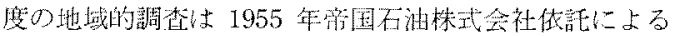
橋本进

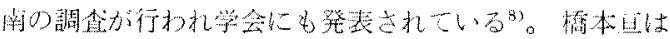

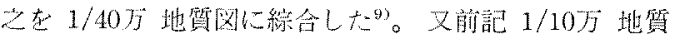
图幅地域周囲での $1 / 5$ 万地筫图幅が現在続々上判行中

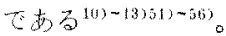

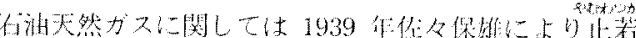

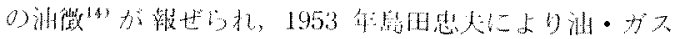

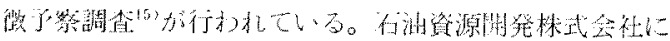

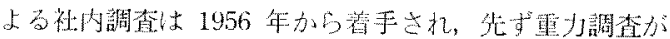

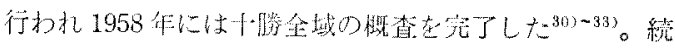
いて同年度から 1960 年送に $1 / 2 \%$ 1/2.5万精度の地

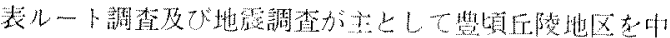

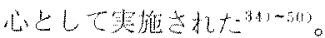

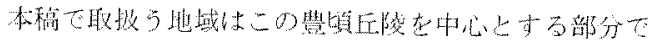
ある。

\section{B. 研究地層}

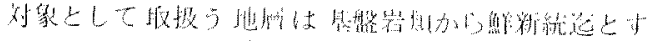

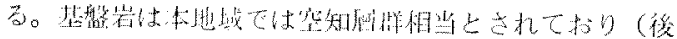

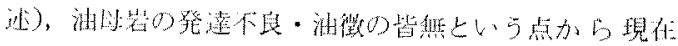

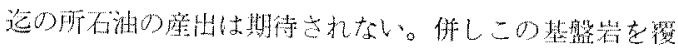

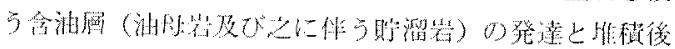

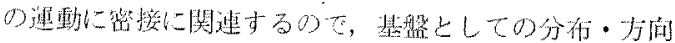

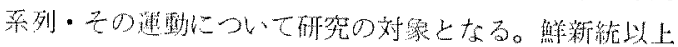

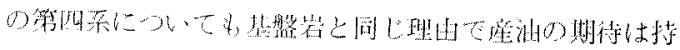

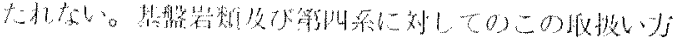

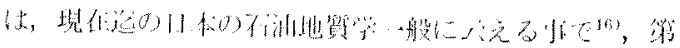

四系は油徽が見出されても，それが地表に露われる場合 せ名坑井浅所で発見される場合でも，㨁下に第三系，白

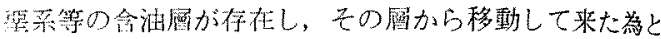
判定するのか嫦識と洘えら扎ている。從って第四系性研 究の刘解加除心大。

\section{C. 研究段階と内容}

(a) 段陛

不油鎹小の探求方法として一般に次の段倩と調查方法

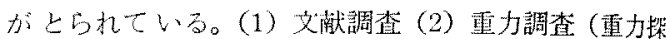

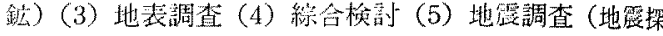

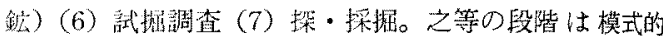
な順序であっで7，現実には必ずしもこの順て実㨢され るとは限らない。寒日本油带の様に，古くから数多くの 地表精查资料や試掘資料があって，之在基にして平野下

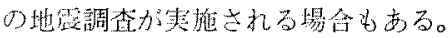

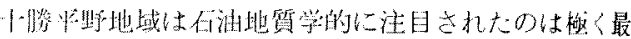

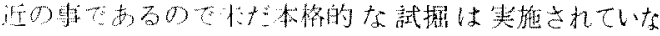

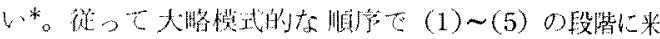
てるい。郭戈の便宜上（4）に雨入したが，この綜合㛟 討は唼密にはどの段階に入るというものではなく，常に 行われているものである新しい調查資料が得られれ ば，そ机によって部分的に，時には大幅に予想を修正し 次の調查の基本方針となる为のである。本稿で籍者の取

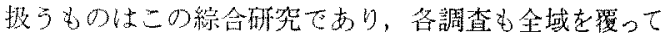
完了しているわけではない策を打断りしておく。

(b) 䂺究の内容

（1）堆皘盈地の規定 集淤構造の探水には，先戈乙

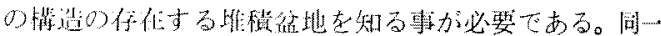

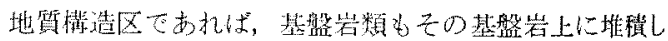
た地虽の迤った地次も间样てあるが，同一構造区の中で

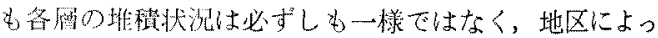

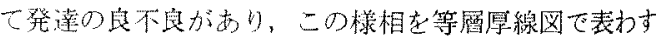

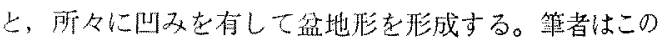

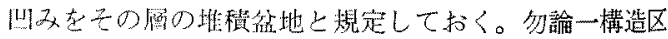

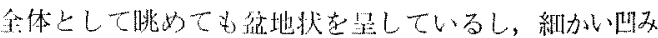

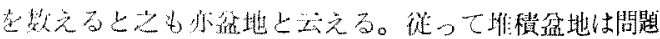

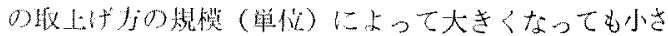
くなって子差支えないと㱛える。

篗者は石油地犋学的立場加らの堆積盆地として「その

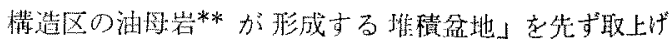
る。その理由は石油鉣果成立の根本条件上して(1)普遍的 な相当の原さの油四碞が発渞する事，(ㅁ)その油姆岩の近

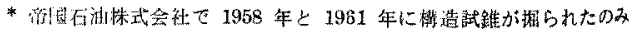

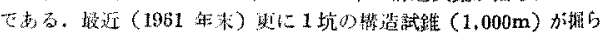

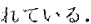

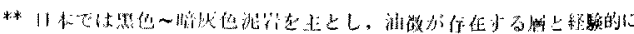

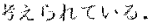


くに畄当な䝪溜岩の存在する事，(油母岩から䝪溜岩に 移動して来た石油が，集皘され保持されている事が必要 てあるが，之等の条件は凡て堆䅡盈地を単位として検討 されるぺきであるからである。即ち石油は油母岩の堆皘 盆地内て移動集積を行うからである。少しく付言すれば 石油の移動集積㙨構について最近三土知芳(1) ・石田義 雄 ${ }^{19}$ が綿密な研究を行い, 石油は油母:岩の堆積と同時に 移動を開始し、鉣床は堆積盆地上の位置に密接な関係が あって盆地斜面の上部位膡に形成されている事が指摘さ れている。それでこの移動集䅪の理論から，上記の石油 は油母岩の堆積盆地内を単位として移動集積するという 事が薄き出される。

（2）集油構造の検棓集消棈造は晲盾の日本では背 斜構造以外の棈造は探鉱対象とされていない。又背斜で あっても経昘的に稼行に足る量を含む油酋の発達が期待 出来ない様な小規模な背斜や，基盤に近接した背斜は集 油構造には含めない。

1954 年石非基裕 ${ }^{20)}$ は，地層が傾斜し始めると石油は 孔隐的な通路を経て，up-dip の方向に移勒し炲めると考 え*，八橋油田と西接する無出油背斜の例老等げて「八 橋背斜は各油層の堆皘期間を通して次第に形成された為 石油の集樻に極めて条件がよい。一片西侧の無出油背斜 は, 石油が八橋背斜に问って移動し去った後で形成され たものである良って集油棈造の価北判定には構造形成 の相対的時期が大切である」慗を述べている。本稿ては この方面からの换討も行った。

（3）推論の基碐資料 上記の検討に際し，をの基潜 資料が不正確であれば検討結果も自から不正碓になる。 従ってまず順序として層序・対此・棈造・含油層等の基 礎資料を記載し併せて堆積環境の推定等を逊へ，続いて 之に基づいた堆積盆地及び情造発達史についての見解に 移り，今後における問題の所在を挙げて結ひたい。

\section{III. 層序}

地域内に露出する地尿は，白方川・十腾川流域及び河 幌断層によって連続を絶たれている。この各々の地区を

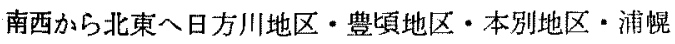
断層以東と呼ぶこととする。之等の各地区に分布する各

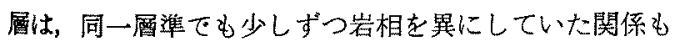
あって, 従来別々の地㖤名がつけられていた。本稿では 出来るだけをれに彷う事とし，止むを得ない場合におい てのみ筆者の新称を用いる事とする。东ず盗料の比榕的

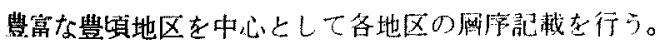

\section{A. 䁗頃地区}

\footnotetext{
*的郤三土・石田は之を理諭的に追求した。
}

南は当縁迄，東は十勝川及びその支流租別川迄，北は 十勝川を越えて北方整流枝内迄を含む。四は国鉄広尾線 迄とするが，第三系は余り路出していない。

(a) 基盤岩 ( $⿱_{\Perp}$ 系? )

霎 頃 㵻

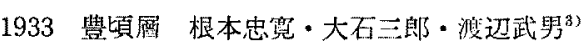

1933 " 根本忠宽・侁々保排”

[模式地] 豐頃村大川上流。[分布] 模式地の牛首别 川上流，忠類村明和北力の当緑川上流に大塊をなして露 出するほか，北方の大川部落と幕別町中里を結孔線上の 丸山三角点 $(331.2 \mathrm{~m})$ の高地を形成して㽝出する。[炭

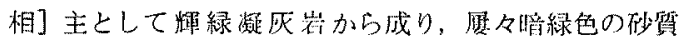

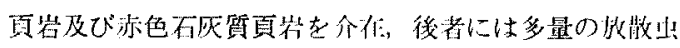

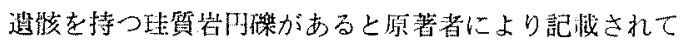
いる。併し所により桌越する征が䔬なる様で，牛首別川 上流西部 (やや変成を受けた黒色頁岩が主で赤色チャ一 卜・石灰岩子ある), 当縁川上流(苏色手ャ一ト主), 生 花苗川上流(輝緑凝灰岩主)，㚘山三的点(鼠色貝岩と千 ヤート)である。[化石］前記枚散虫以外杜だ発見され ていない。[備考] 原著者等は当時の知識加ら古生臂 （?）と仮定した。1955 年根本忠寛は岩相の類似から兒

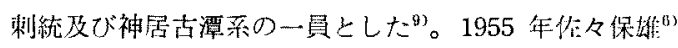

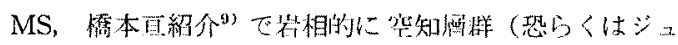

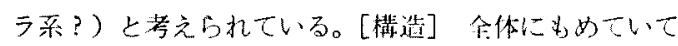
摗めない。

(b) 新第三系

(1) 一勝藻別尿群 (新称)

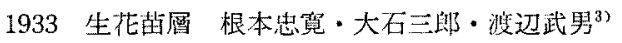

1933 生花毕層下部 根本忠筧・佳々保婎”

1955 ノヤウシ庼任々保雄 ${ }^{6)} \mathrm{MS}$, 橋本亘紹介 ${ }^{2}$

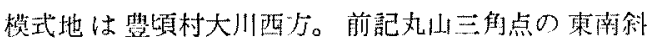

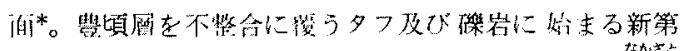

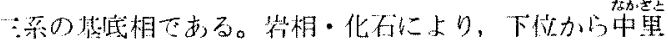

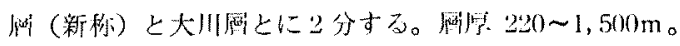
i) 中里廨 (新称)

岩相的に上下部に分けられる。[模式地] 前記丸儿三

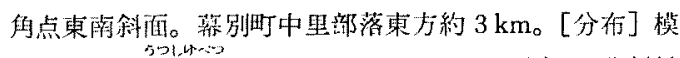
式地と南方牛首別川上流。テ活キレナイ西方の背斜軸 部。上部層の当縁川上流にも分行。[岩相]下部：模 式地では緑色夕フ，艾武岩質或は安山岩質熔岩・集塊

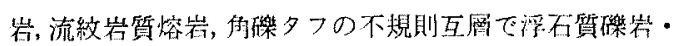

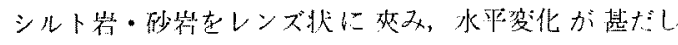

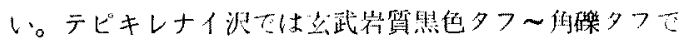

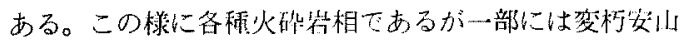

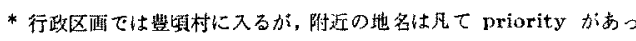
て名つけられないので,この名をとった。 


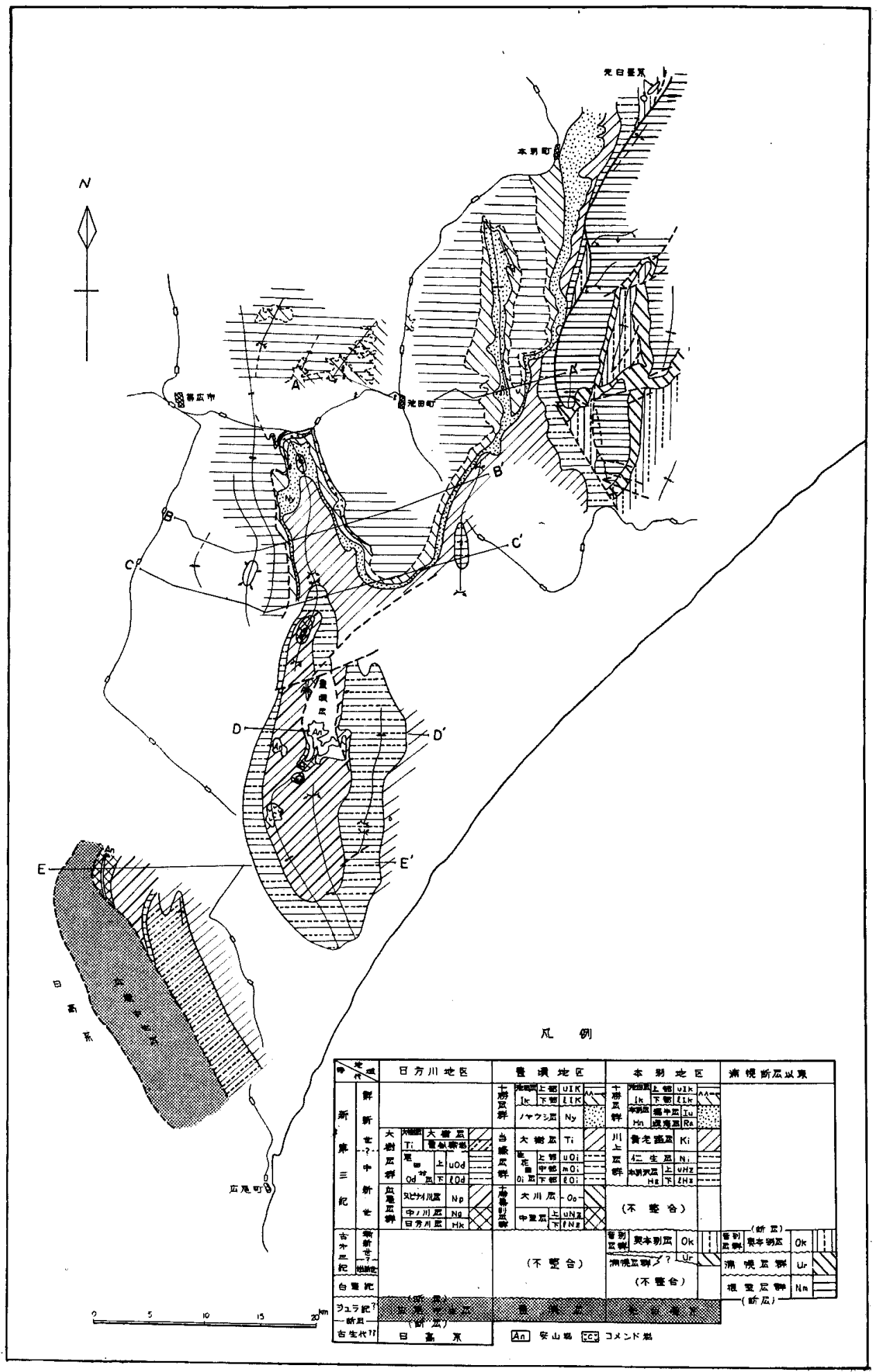


第 2 図地丝断面図

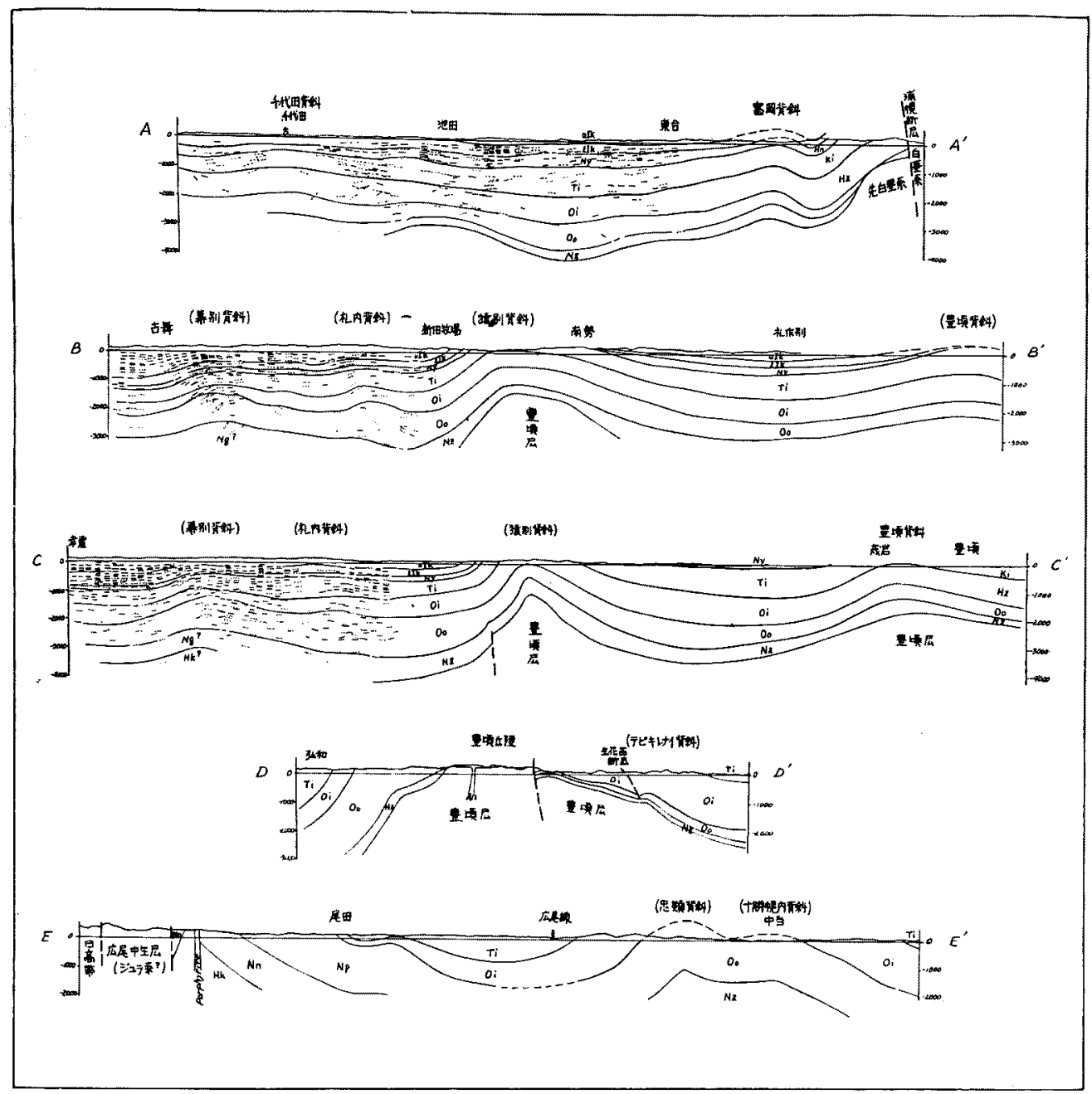

皆質のものもある。上部：乱堆䅡状磁岩，時に泥岩・仯

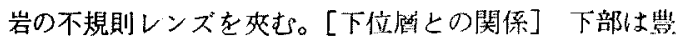

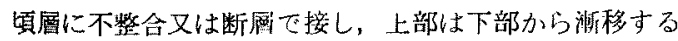

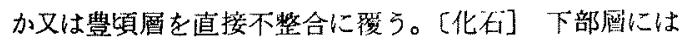
未発見。上部層には有孔虫を産するが後で一括述へる。 [層厚] 80 250m。[備考] 下部圓は岩相的に十勝平野北 方に分布する㹸加緑色夕プに対比出来る。伎々等の ノヤウシ凮の名称は筆者のノヤウシ畨と翼層準同名て priority は前者にあるが，石油会社で既に後者が通用し てしまった為採用しなかった事をお断りする。

ii) 大川層

1933 生花翰層・生花苗娄下部。前揭

1955 大川層 任々保雄 ${ }^{62} \mathrm{MS}$, 橋本旦結介 ${ }^{92}$

[模式地］豊頃村大川西方。丸山三盾点に向う沢入口 の橋の䄪 $2 \mathrm{~km}$ 上流加ら, 上流 $2 \mathrm{~km}$ の間。[分布] 中

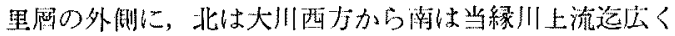
分份する。[岩相] 下部はタフ質チョコレート色泥岩を

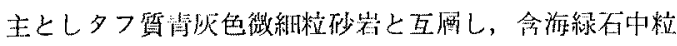

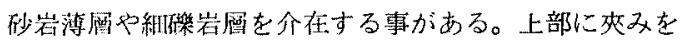
減じ最上部は全く塊状となる。砂㜀岩の夾みは圆間褶曲 状を呈する。ノヤウシ川上流では泥岩中に粗悪炭や赤色 チャート磁が含まれる所がある。[化石] Makiyama chitanii (MAKIYAMA) の他有孔虫を産出する。[下 位屈との関係]下位の乱堆䅬状の著しい㜰岩層の上限を 以て中里層と分ける。大川層中の上下部游移的飞且互 に岩相变化をする。併し本層最上部は必ず垷状泥岩相て

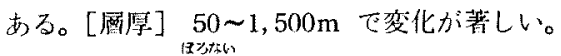

iii）十勝掝内愿について

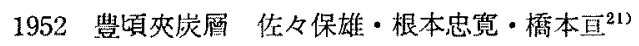

1954 " 任々保雄・橋本亘, 他 ${ }^{22}$ 


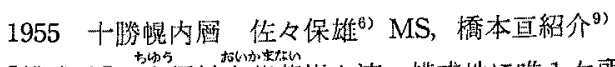

[模式地] 忠類村生花苗川上流。模式地に㫿 1 ケ所麗 頭が知られているのみで地哲図には示し得ない。[岩相] 淡灭色紗岩上暗灭色泥岩砂岩互層で褐炭を介在し㖤得約 $30 \mathrm{~m}$ 。[化石] 褐炭加ら水葉支産出する他, 互原部加ら Cipangopalaludina sp., Lanceoralia sp. 等淡水目類を

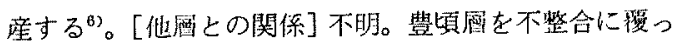
ているらしいが，上部中里厤の下位に簬出する。それ故 上部中里尿又は下部中里䚄の一部か，或は又その下位の 本地域最下位第三系か程々の case が考えられる。[借 考]中里層中の層か，更に下位㞗であったにしても，岩

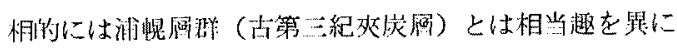

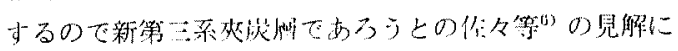
间意したい。

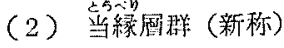

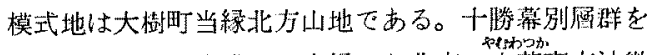
整合に得い，乙を取巻いて当緑加ら北方へ肯若南方油街 地迄分布する。岩相・化石から下位の生花苗層上上位の

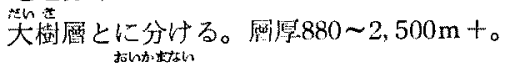

i) 生花酳層

1933 生花苗層 根本忠筧・大石三郎 - 渡辺武男 ${ }^{3}$

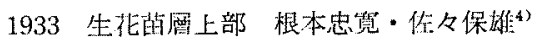

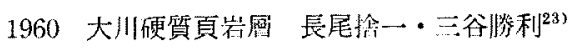

倠相的に上中下に 3 分出染る。

[模式地］大樹町生花苗上流テピキレナイ沢。[分布] 大樹町当緑・忠類から北方ノヤウシ川上流迄，大川虽を

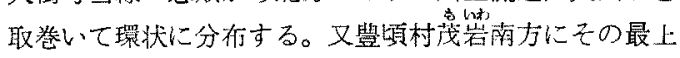
部が顔を出す。[岩相] 硬質頁社を主体とするが，中部 に條相が発澾するので 3 分出来る。下部：いわゆる板状 挭質頁岩で著しい層間褶曲状を呈する。一部細精砂岩と の緗互冨を星し又泥灰岩団塊を有する事がある。模式地 をはタフの夾多が多いがこの岩相はむしろ例外的で，テ ビキレナイ沢入田から悓う $1.5 \mathrm{~km}$ 間を模式とするうが

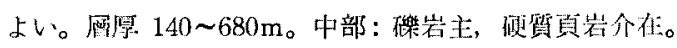

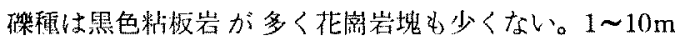
間の単位で graded 老綵这し，碩の大きさはその基底で $5 \mathrm{~cm}$ ，上限では $1 \mathrm{~cm}$ が篦通である。基質は夕フ質砂岩 又はタフをある事と，硬質頁岩の夾みが増すと層厚も厚 くなる掔が特徴的である。ノヤウシ川上流や忠類网方で は本層は硬質頁岩と交指状に岩相変化して上下の岩相と 区別がつかなくなる*。程质 90〜870m。上部：下部と同

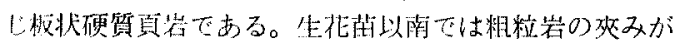

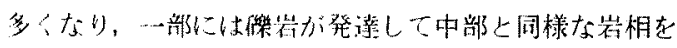

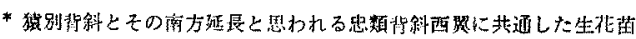

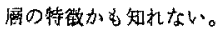

呈する。層厚 $60 \sim 700 \mathrm{~m}$ 。[化石] テピキレナ1沢本層 上部から Yoldia cfr. tokunagai YoK., Macoma dissimilis MART., Thracia pubescense PULTENY を産する4 他 Makiyama chitanii (MAK.) を一般に 産する。[下 位層との関係]大川履とは整合で，基底はタフ又はタフ 督砂岩があり明膫である。上中下各層の境界は岩相的に 区分が容易てあるが前述の梾に不明となる所（猿別背 斜・忠類背斜西翼) むある。[㞗厚] $300 \sim 1,700 \mathrm{~m}$ 。[借 考] 長尾等の大川硬質貝岩尿よりも住々の大川層の方 が，地圂名として priority あり長尾等も仮に付した 名称と述へている。佐々・滗者の大川履は長尾等の大川 榧質頁岩屬の直下の䦗である。

ii) 大樹原

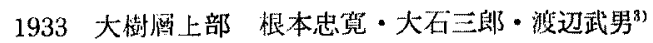

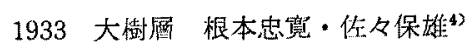

1960 茂岩泥岩層 長尾捻....三谷滕利 ${ }^{232}$

[模式地] 日方川地区参照。潐模式地として生花苗附 近の標高 $100 \mathrm{~m}$ 内外の台地が誉げられているい。[分布] 当縁部落力ら北方台地它経て止若南方の油徽地迄。[岩 相]带緑灭色シルト岩。球藻を含有する事が多く風化乾 燥すると白く㭴くなる。黑色粘土岩・細粒砂岩の不規則 レンズを夾古事がある。下部は比校的夾みも婗則正し く，数多く入っているが上部は塊状で粒度も荒くなる。 ノヤウシ川上流では本層の下部 $500 \mathrm{~m}$ の間に䃯岩が介在

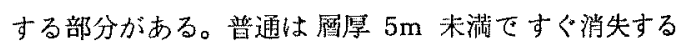
が，一つだ圆厚 $60 \mathrm{~m}$ むあり，分級の慙い $30 \mathrm{~cm} \sim 3$ $\mathrm{mm}$ 迄の古期岩（粘板岩・砂岩）を主としシルト岩の同

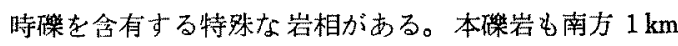
の沢では消失して連続しないが，その層準に当る部分は 脈岩状の砂岩が不規則に走り異常堆積を示す。この異常 堆積も南方に消失する。又本層下部には落差 $1.0 \sim 15$

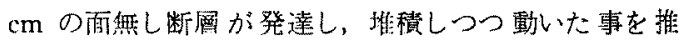

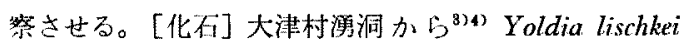
SMITH, Macoma dissimilis MART, Tellina? sp., Miltha (Lucinoma) annulata (REEVE), Thyasira nipponica YABE et NOMURA, Solemya tokunagai YoK., Natica yanthostoma DESHAYES, Nassa sp., Dentalium sp. を，当縁川左岸加ら Yoldia sp., Dentalium sp. を,ノヤウシ川上流や幕別町糖内附近から Thyasira sp., Nuculana sp., Yoldia sp., Tellina sp. 等を産する。又 Makiyama chitanii (MAK.) 多産するが，本䉚がそ の産出上限となっている。有孔虫化石は少ないが球落化 们は䇺富で之については一括後述する。[下位圂との関

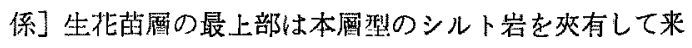
て浙移する。淤移带の厚さは数 $\mathrm{m}$ の場合が多いのて此 䧶的明膫に境が引ける。ノヤウシ川上流でも同様である 
が，此妱ては本層最上部に生花苗属の硬質頁岩塊又は砂 岩塊を乱堆積状に取込んだ部分（層原にして数 $\mathrm{m}$ ) が 䁌察されるので，単なる整合渐移関係とも思えない点も

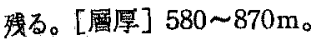

\section{(3) 十勝層群}

1953 本別層群十池田層 位々保雄 ${ }^{24) 25)}$

1955 橋本 巨是 $^{9}$

1958 十勝層群 三谷勝利 $\cdot$ 小山内熙・橋本亘 ${ }^{(0)}$

1959 十勝層群 三谷勝利はか ${ }^{11)}$

模式地は本別地区 $1 / 5$ 万足等太 ${ }^{10)}$ 及び本別区愊 ${ }^{11)}$ 内 にある。岩相・化石から下位のノヤウシ尿と上位の池田 屬に分つ。豊頃村茂岩から西方石神を通り幕別町中里を 結ふ線から北方に分布する本尿样につき述べる。茷岩の 南方队湧洞東方に亘っても，本尿群の分有する資料はあ るが地質図として繹める迄に十分ではない。佐々・橋本 が本別層群と池田層とを統合して十勝層群とした理由は 文献 10）p. 25 に示してあるが，筷者の考えではノヤウ シ層（二本別層）と池田層とは後述の稼に不整合の度合 む堆積環境の差も可成りあるので，旧のままでよいと思 えるが，一応この分け方に従って就く。[層厚] 440〜 $860 \mathrm{~m}+$ 。

i）,ヤウシ層 (新称)

1933 大樹層 根本忠宽・大石三郎・搌辺武男 ${ }^{33}$

1955 本別原 俈々保雄活加

1957 石神層 吉田三郎 ${ }^{26)}$

1960 棣内砂岩層 長尾捨一. 三谷勝利 ${ }^{23}$

[模式地] 豊㛝村ノヤウシ小学校酉力 $500 \mathrm{~m}$ の北へ流

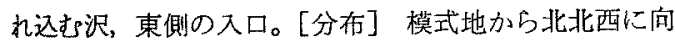
、猿別川コボレ坂附近に出て(この間コボレ坂南東方て 池田層基底の不整合て不除し）南転して猿別川西岸の段 丘層の下を走り新田牧場の沢から南東に向い糠内南方の 沢迄連続する。模式地の南へは石神部落に向い, 東へ户 向を転して茂岩部落北万人拔ける。[岩相］塊状緑㭱任 シルト岩を主とし $50 \sim 100 \mathrm{~cm}$ の青欤色絹粒砂岩と互譄 する部分む発達する。シルト岩は下位の大樹層のものと 酷似するが Makiyama を含まない点と上部のものは粗 粒となる点で区別する。又粗琹炭を夾む部分もある。猿 別背斜東翼ては西翼に比し，又南程粗粒となる。[化石］ 滰川本別化石群の代表種 Fortipecten takahashii(YOK.) 産する。産地は豊頃村石神・ノヤウシ川南北から竹内 牧場の沢迄 5 力所の猿別背斜東翼に連続して見られる か，西劕では木だ発見されていない。その他 Solemya sp., Acila sp., Thyasira bisecta CONRAD, Lucina sp., Cardium sp., Dosinia sp., Tellina sp., Macoma sp., Solen sp., Mya sp., Natica sp., Fulgoraria sp., Balanus sp., 等の浅〜類海貝化石老産する專が多い。有孔

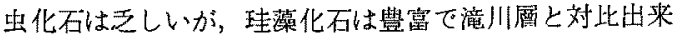

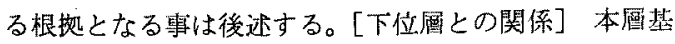

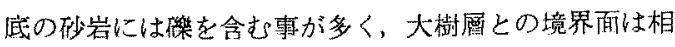
当著しい四凸を乐す。本別地区では下位風とは著しい不 整合であるが，本地区では平行不整合と考えられ特に猿 別北斜西翼では殆ど整合的に観察される。[層厚] 0 $200 \mathrm{~m}$ 。[供考] ノヤウシ㴔の名称についての priority の問題は既に（b）（1）i）で断わった。

ii）㳐田属

1932 池田屬 大石三郎・渡过武男 ${ }^{3)}$

1933 池出層 根本忠筧 - 大石三郎 - 渡辺武男

[模式地] 池田町西方の十滕川沿岸。[分布] 模式地 の北方全域及びノャウシ層の外儧に沿って分质する。 [岩相了含黒雲回細精砂岩・砅岩・泥岩・シルト岩・タ フ等から成り，乘炭の発達が良好である。本層の層序に ついては岡崎由夫 ${ }^{27}$ ・長尾捨一・三谷勝利 ${ }^{23} に$ により詳細 な研究が行われ細分されている。十勝川以南ては砂・棌 層の卓越する下部と，泥岩の夾みの多くなる上部とに分 れるが，丁度その㑽になる厚い夕フ層基底を以て本稿で は 2 分した。このタフは十勝平野の相当範囲に亘り鍵層 となると予想される。下部：分級の上い黑雷母青死色儿 一ス砂岩を主とし時に集をcross-laminae 状に含有する。

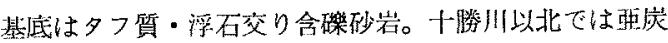
圆の発達著しくなり檬行されている。層厚 $180 \sim 350 \mathrm{~m}$ 。 上部：基底のタフは層厚 10〜15m で白色浮石質・ヘン トナイト質で覀炭層を夾有する事がある。基底に縕独粗 砂を伴なう事もある。その上位は含雲母ルース中細粒砂 岩を主とし，猛岩・浮石タフ及び帶炭を類繁に夾む。又 青灰色タフ質泥岩〜シルト岩を夾むが，時には大樹層や ノヤウシ畨に酷似した岩相も見られる。層厚 160〜360 $\mathrm{m}$ 十。上下濖を通じて㕵相の水平変化甚たしく, 特定の 要炭・タフを追跡して棈造を判定する方法しか無い。俵

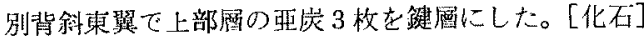
本層下部加占 Anadara sp., Chlamys sp., Cardium sp., Meretrix (?) sp. を産する。上部からは猿別背斜西翼を Pecten yossoensis YoK. の他枺整理の Acila, Arca, Septifer, Mytilus, Cardium, Fulvia (?), Venerupsis, Gomphina, Dosinia, Meretrix, Mactra, Spisula, Tellina, Macoma, Solen, Mya, Callana (?), Calliostoma, Crepidula, Natica, Siphonalia, Rapana, Nassarius 等 を産し，背斜東翼では Raeta を産する41)。古く命名 者等34によって報ぜられている蝶多南方・長流枝内川 一支流奥の Elphidium sp., Milta annula DALL, Cardium muticum REEVE, Mya arenaria japonica JAY, Macoma inquinata congrua (MART.), Tellina venulosa SCHR., Mactra sp., Gastrana yantaiensis CR. et 
DESH., Natica yanthostoma DETH., Trophon? sp., Chrysodomus cfr. modestus KURODA, Buccinum sp., 等の瀕海動物稚集凶滗者の上部層に属する。之等の貝化 石から全般に浅海～潟（？）の推積物であるが，猿別背 斜の東側では内湾，西側では浅〜瀕海の環境にあったと

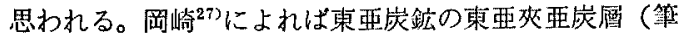
者の上部池田虽の下部）から Menyanthes trifoliata L. の奏及び湖沼成の監鉄鉣を産するとあるが，猿別背斜粙 部近くでは特に陸地に近い環境があったと考えられる。 [下位層との関保］不整合を以て下位層に接する。この 不整合の形は一般にはノヤウシ㬝を㖟うが，猿別背斜東 翼のコボレ坑（此若油街地南方）では同層を欠いて直接 大樹層に接する。又下位層への㙏政形式の不整合である

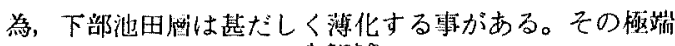

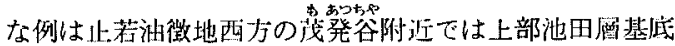
近くが，ノヤウシ層に接している。[屬厚] 340 680m 十。[侕考] $1 / 10$ 万大樹図幅の当時は池田層とその上位 の带広層とは整合と予想されていたが，現在原著者の一

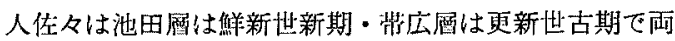
者は不整合関倸にあるとしている24)。篚者の見解む同様 で，池田層迄は地層傾斜を持って褶曲しているが带层層 は曻ど水平な高位段丘推積物と考える。併し池田呞の傾 斜が平になっている所て，しかも上部池田监の集岩に接 する様な場合，再者の区別は鹳しくなるが带広圂中には 俗称十勝石（黒睢石）が含まれているので分雖する事が 出来る。

\section{B. 日方川地区}

大樹町を過ぎる日方川（現在は歷舟川と呼ふ）以南の 地区である。1933 年")以来十勝平野地域の層序の模式地 となっているが後述の様に疑問も多い。

(a) 基盤岩類

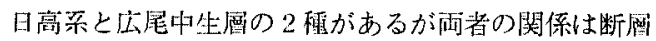
である。新第三系は広尾中生䐓に接するがこの関係も断 虽である。

（1）日高系 (日高層群)

1933 日高古生層 根本忠寛他 ${ }^{8}$

1934 日高系 鈴木醇・山口四郎*

本系は定義の朋滕でない地層であるが，日高構造带を 構成する古期堆䅡岩に対する名称である。根本等 ${ }^{3)}$ によ れば，本系は岩質上加ら砂岩带と粘板岩率に分けら机本 稿符罒はその砂岩带に属する。主として緻密堅硬な可黑 色微納粒砂岩の愿虽から成り，いわゆる輝緑凝灭岩類似 の带綜顾色仯岩と互層するが，部分によっては粘板岩の 薄層と夾在する事も少なくない。本稿笵围西南端に分布

\footnotetext{
*文献 9) p. 8 《び交献 28) 1959, 1 月号 p. 14.
}

する。

\section{（2）広尾中生風}

1933 広尾中生層 根本忠寛 - 估々保雄")

[分布］日高系の東側に带状に南北に分布する。[岩 相］主に黑色頁岩〜暗灰色粘板岩と喑灰色砂岩との互

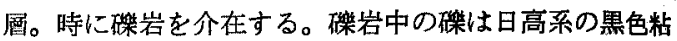
板岩・砂岩・石灰岩・玢岩・花崗岩等である。佐々の意 見では空知層群*の一員と考えている（佐々教授談及び 文献 9) p. 9 注)。

\section{(b) 新第三系}

\section{（1）広尾層啡（再定義）}

1933 広尾層清 根本忠寞・住及保雄4)

榄式地は日方川及びその支流である。広尾中生層分布 地带の東側に分布する。原著者等の定義によれぱ下位か

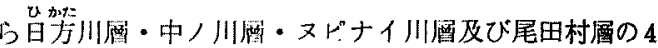
累層から成るとされている。併し尾田村層は本稿では不 整合こそ確認されなかったが，北海道で最む堆皘盆地の 拡がった（海浸の普痛的な）層に対比出来ると考えられ るので, 之を上位の大樹層群の下部層に繰入れる。層厚 $3,050 \mathrm{~m}+$ 。

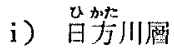

1933 日方川圆 根本忠寞・伀々保雄

［模式地］日方川パンケ附近又は中ノ川中流。[分柎］ 中ノ川と日方川の間に带状に分布し，中ノ川以南ては広 尾中生層との境界の断層の為間むなく分布が消える。 [若相］脆いタフ質中粒砂岩から成り薄い小磞層を夾む。 [化石］原著者等により日方川とその支流から Thyasira nipponica YABE et NOMURA, Yoldia off sagittaria Yok., Leda sp., Venericardia cfr. orbica Yok. Chrysodomus sp., Turritella nipponica YoK., Dentalium sp. を産する。有孔虫化石は出ない。[下位陌との関係］ 最下位は玢岩と断層に接する為不鹏。[層厚] $300 \mathrm{~m}+$

ii） 中八川俤

1933 中八川層 根本忠寛・佐々保雄4

［模式地］日方川支流中八川。[分布］日方川層の東 西両側に簬出する。[岩相] 下部は暗灰色夕フ質砂岩及 び同質泥岩の厚い渐移互層で，上部は板状互層を呈す る。[化石］従来原著者等による海綿 Monactinellid の 破片以外に化石は知られていなかったが，最近有孔虫化 石により中新世中期を示す資料が得られた（後述）。[下 位層との関別］日方川層とは漱移。[層厚］ $1,100 \mathrm{~m}$ 。

iii） ヌピナイ川屏

1933 ヌピナイ川缕 根本忠寛・佳々保雄")

［模式地］日方川支流ヌピナイ川。［分布］中ノ川首

* 北海道中央部ては白垔系のエソ徬群の下位属でシュラ系又は一部白 垔系と教えられている。 
の東側に東頃斜て分布する。[岩相］下部は暗欧（チョ コレート）色のタフ䁩泥岩で，上部にやや粗粒となり大 川層上部の泥岩に酷似する。垉状を示す事が多い。[化 石了ペンヶ川に Natica yanthostoma DESHAYES, Turritella cfr. saishuensis YOK., Dentalium sp., Yoldia sp., Nuculana sp., Venericardia ferruginea (CLESSIN), Venericardia sp., Spisula sp., Macoma tokyoensis MAK. 等がある゙。最近有孔虫資料が得られ中新世中期 を示す事が確証された。[下位㞒との夙係］濑移とされ ているが，有孔虫群集の変化は明瞭であるので梌楌を要 する。[盗蟹] $1,750 \mathrm{~m}$ 。

(2) 大樹㬝群 (再定義)

1933 大樹酋分布地 根本忠筧・住々保推"

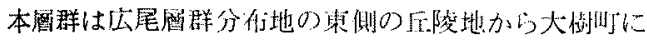

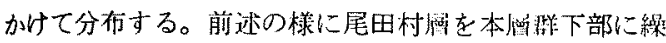

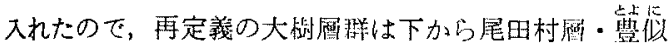

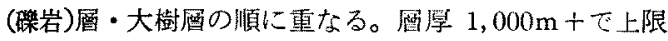
は分布していない。

i) 尾田村層 (尾田村)

1933 尾田村層 根本忠寛・仿及保雄 ${ }^{4}$

[模式地] 中ノ川と日为川合流点尾田村附近。[分

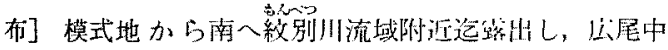

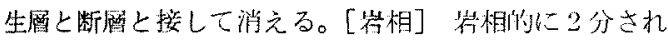
る。下部：尾田村緑色㫾岩属と呼ばれ，緑色砂岩を主と しヌビナイ川層型の泥岩と互層する。緑色砂岩には海緑 石粒を念んている゙〉。本岩相は下部生花苗層の基底近く の緑色础岩及び大川廙型泥岩との互呞（ノヤウシ川上流 てよく㓋察される。）の様子と全く同様である。的厚 80 mo上部：尾田村板状頁岩屬と呼ばれ，灰白色〜䁬灰色 板状硬質頁岩である。欧白色夕フ買砂岩・暗兏色粗粒砂 岩の薄層を介在する。本岩相も亦前記ノヤウシ川上流の 下部生花苗䚄によく似ている。[化石] Makiyama chi-

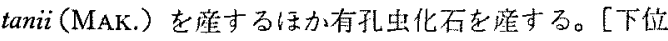
層との関係]含海緑石仯宕の基威を以て明㮩にヌピナイ 川層と境される。尿厚 $110 \mathrm{~m}$ 。

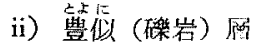

1933 豊似川層 根本忠筧・径々保碀:

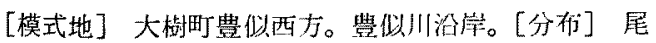
田村層の東側に州状に南北方向に分布。[岩相］原記载 によれば主として俕岩・砂䓄磞岩・粗粒矽岩力ら成り， 時に砂岩・磻岩を夾在し又団塊を含む事が多い。磁は黑

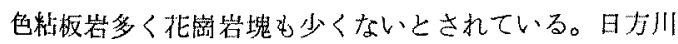
の本層は小背斜を形成しているが，この部分には乱堆積 が発達している。［化石］産出しない。[下位确との関 係了分布から見て 不整合と解せざるをえない。この分 布については別な考え方 (後述) が成立し，整合とする
可能性む残っているが，確定的な資料の無い現在原著者

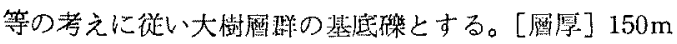
to

iii）大啮闰

1933 大樹層 根本忠宽・传:々保推 ${ }^{4}$

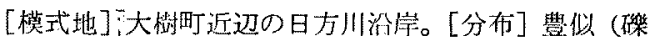

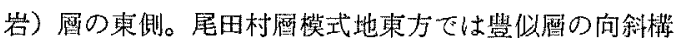
造部に分布する。[岩相] 岩相上から上下 2 分される。

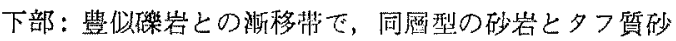
岩・泥票の互圈。上部：下部加激次夾子を減して塊状

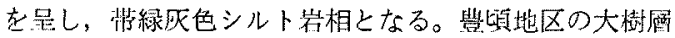
上同じ岩相である。[下位虽との関係］上記の㥞に漱移。

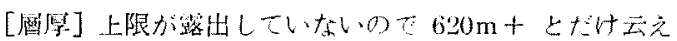
る0タてある。

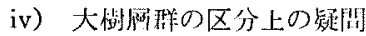

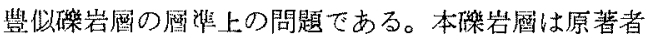

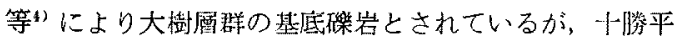
野では本地区にのみ発達する特殊な崔相てする。その記

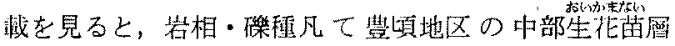
（础宕相）に酷似するのみならず，尾田村尿の上部は下

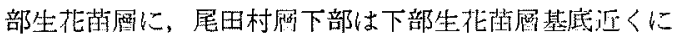

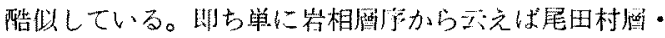

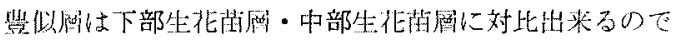
ある。とする時䏕点が2つある。1つは㩐造であり $1 つ$ は上部生花苚尿の得志てある。本稿の地質図は原箸者の ものと 1955 年佐々等の再調查の末公表資料7る綜合し れものであるが，旧資料とは多ど変ってはいない。この

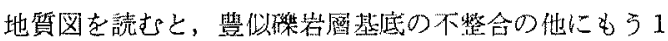
つ大樹局基底の不整合が考えられる。原著者等は宕相の

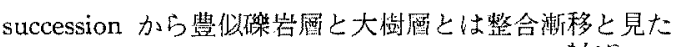

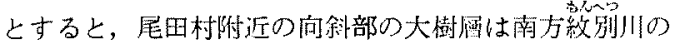

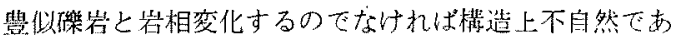

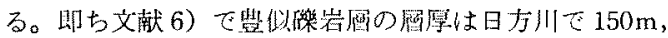

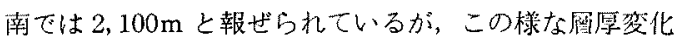

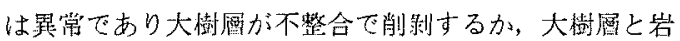
相变化するのでなければ説明し瞧い。更に又上記向斜の 東側の豐似層の形成する背斜を示す走问傾斜は乱垃積地

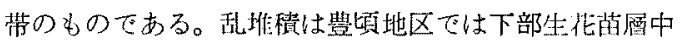
に多く，又大樹層の下部にもあるが(この点ては大樹層 下部とする考充む成立する)，何れにしても日力川流域近

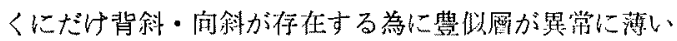

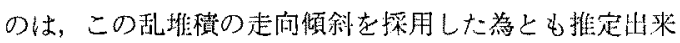
る。そこてこの走向傾斜が舆視出来て本地区の一般傾向 の州落ち単斜とする考えも成立する。一万乱堆積状でも この走问傾針を信用する立場をとれば，類型优当綵北力

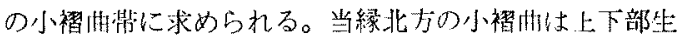


花苗層の東傾斜間に夾まれて，中部生花苗層で形成して いる。上記の豐似保岩の異常な層厚変化も，中部生花毕 層であればある程度同様な層厚変化を持っているのであ

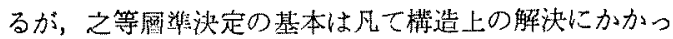
ているのである。

次の問題の上部生花苗層の存否であるが，篚者は本地 区の大樹層の下部に上部生花苗層相当部があるのではな いかと予想している。例えば豊頃地区のノヤウシ川上流 では，上部生花苗層の尿厚が $80 \mathrm{~m}$ 位迄薄化しかつ大樹 層型のシルト岩が卓越する所がある。このシルト岩のみ を注目すれば，中部生花苗層の鿬岩の上に直接大樹層が 㦲る様にも見られるであろう。日方川ルートでも，似た 現像があるのではなか力らか。領者は良って尾田村層は

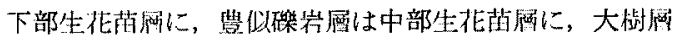
としている部分の一部は上部生花苗層に对比する事が出 来るのではないかと予想してみたが，之を確める機会が 無かったのて，今後の問題として今回は従来の考えに徉 う事とした。

\section{C. 本別地区}

豊頃地区の東方に当り，西は十勝川・利別川，東は浦 幌断層で仕切られた地区で本稿では本別町を北限とし た。数年前から $1 / 5$ 万図幅が刊行さ礼資料名明膫になり つつあが汉面種々の疑問为生して来ている。

（a）基盤岩（ジュラ菜?）

少白垔系 (空知層群?)

1958 先白惡系 三谷勝利・小山内熙・橋本亘 ${ }^{102}$

［模式地］本別川上流の幽仙境地域。［分布］本稿地 域内では模式地にのみ露出するが，北方では浦㗪断層の 延長西側（櫂物川流域・螺湾川の中央橋附近）に点々と 顔を出す。[岩相] 黑色〜暗网色の板状硬質貝岩を主と し，洔に粘板岩・腤灰色粗柆仯岩・灰色夕フ等を欢を。 原著者等によ扎ば，模式地以外の原は又買った岩相で稲

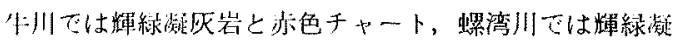

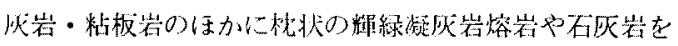
伴なうとある。岩相的には䇺垻層に似る。[化石] 原著 者等によれば石灰岩中には生物選体が浔められたが，属

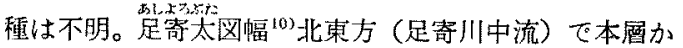
らStylina sp., Montastraea sp. 等の化石があり, 前者 は鳥/舁石灭岩以外加未だ発見されていない属とされ ている(1029)。[上位屏との関保] 本別川では奥本別㖤に 不整含又は断屬関係を以て接するが，北方では本別凰

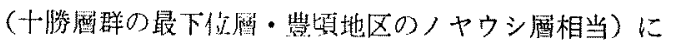

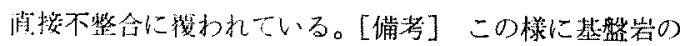
上には白型系は栈らすに占第三系の最上部，或は新第三 系中新世上部層か淔接している事は非常に興味あり䨘大 な事実であり，之については媵述する。
貞

(b) 古第三系

(1) 浦帽層群

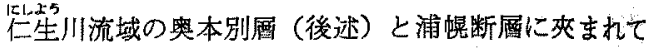
浦愰層群最上位層（尺別層）が舆本別層に不整合に復わ れて簬出する。浦幌層群は始新〜漸新統と考えられてい るので ${ }^{10113)}$ ，浦幌層群最上位は漱新統であろう。尺別䉚 と白㤠系及び先白垔系との関係については，筆者は浦䗷 断層が後述の様に重要な構造線と考えているので，その 考之によれば仁生川流域の尺別酋は先白峛系に直接する と解したい。浦幌尿群の記載は浦幌断圆以東の項に誶 る。

\section{(2) 揞別尿群}

1957 音別原群 棚井䰻雅 ${ }^{13}$

原著者の $1 / 5$ 音別図幅て命名され釧路炭田西部に発達 する。下位から染路・䋖別再圈に分ち，夫及石特炭田の

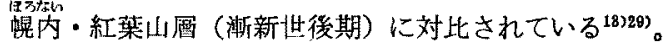
本稿では $1 / 5$ 万本別図幅に従い余路・䋖別を一括して奥 本別層として説明する。

奥本別層

1958 奥本別屬 三谷勝利ほか ${ }^{10)}$

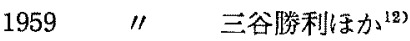

［模式地］本別川上流。［分布］模式地及び上述仁生 川流域。[岩相］下位加ら緑色砂岩・灰色泥岩・タフ質 砂岩の 3 層に分けられている。[化石］緑色砂岩・灰色 泥岩から海棲只・有孔虫化石を産する11)。[下位層との 関係]仁生川及び浦幌断層以東では浦幌層群と不整合関 保。本別川では直接先白㤠系を覆う。根室圆群（白严 系）とはその下位と浦愰断冨を以て接する。[層厚] 300 $\mathrm{m}+$ 。

(c) 新第三系

古第三系の層側に本地区の面積の大部分を占めて分布 する。

(1) 川上筧群

1953 音別屬群 - 直別層十知床層群 份及保雄 ${ }^{25)}$

1957 擪内枯層群 棚井敏雅 ${ }^{13)}$

1958 川上層群 三谷勝利ほか ${ }^{10)}$

1959 川上層群 三谷勝利《か ${ }^{112}$

本別町川上附近を模式とする。岩相から本別讯層・任 尘層・賽老路層に 3 分される。層厚 $700 \sim 1,450 \mathrm{~m}$ 十。

i) 本別沢層

1953 音別層群 - 直別層（渐新世）俈及保雄25)

1957 厚内層群・直別層下部 棚井敏雅 ${ }^{13}$

1958 本別沢触 三谷勝利ほか ${ }^{11}$

[模式地］本別町東方，本別沢部落上流二俣加北 $150 \mathrm{~m}$ 遡った点から更に上流約 $1 \mathrm{~km}$ の間。［分布］模 式地から南方へ带状に分布し，川上流布川で浦幌断層に 
つき当って切れるが仁生川流域で再び顔を出す。活平以 南では，分布の資料は不明てあるが，恐らく存在すると 思われる。[岩相］下部：暗成色硬軟泥岩互層。部分的 にタフ質細粒砂岩も夾まれる。下位程互尿の単位がさ くなり 1 2 cm 每の組居酋である。最下位は你岩。上 部：硬望頁岩を主とし，タフ筫の炏色ルース仯・青炏色 泥岩を夾有する。浦㹸川上流ではこの砂が $50 \mathrm{~m}$ 出姳く 発達している。本別沢では層内褶曲が見られる。最下部 はタフ又は傺父り砂岩を以て下部本別沢層と分ける。

[化石］本層上部加貝・有孔虫化石を産する。詳細は 文献 11）p. 30。[下位層との関係] 模式地では奥本別 層を不整合に椱う。他地域では奥本別層又は白等系と断 層て接する。[層湟] $400 \mathrm{~m} \pm 。$

ii) 坒任生圈

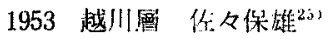

1957 直別箱層の上部 棚井微雅: ${ }^{131}$

1958 仁生層 三谷勝利はか。

1959 亿生層 三谷勝利ほが

[模式地］ 生川下流々域。[分们］模式地では本別 沢屋の两側に他は西側に带状に分布する。浦煶川本流活 平附近で本別層基底の不整合に削られて分布が中断する 所がある。[岩相] 板状便質頁岩。下位程やや熄状。[化 石上部に僅かに放散虫や珪薬を産するのみである。 [下位層との関係] 本別沢層上部と互層渐移。本別図 楅"1によれば，本別川流域オネトップ川下流で一简所本 别沢層と不整合関係と疑わ机る現象が報告されている

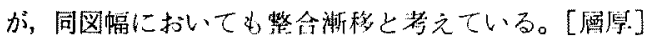
$200 \mathrm{~m} \mathrm{~m}_{\text {。 }}$

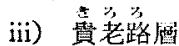

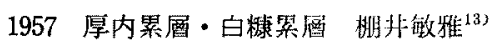

1958 貴老路層 三谷勝利ほか力 ${ }^{10)}$

$1959 \quad "$ 三谷勝利ほが 11

[模式地］本別町東方 $4.5 \mathrm{~km}$ 加 $6.5 \mathrm{~km}$ 迄の本別 川沿いの露頭。[分布] 位生尿の西側に分不。活平附近 で分布の中断するのも生尿分们と同様である。[岩相］ 下部加ら砂岩・シル卜岩・砂岩・シルト岩・砂岩・シル 卜岩の 6 つに分れる。下位と真中の倠岩の下半は舁色粗 粒で主に古期岩粒から成り，海綿・うにの破片が入る。 他の砂岩は淡灰色タフ質て上位程浮石質化している。シ ルト岩は青灰色でタフ質細粒砂の laminae を゙夾むが, 最上位は塊状となる。模式地から南人全層が細粒化す る。シルト岩は豊頃地区の大樹層と岩相が似ている。

[化石] 本別図幅 ${ }^{11}$ 参照。産出数は多いが保存が瑟 い。[下位層との関係］整合。[層滰］ $420 \sim 780 \mathrm{~m}$ 。 (2) 一勝層隦

従来の地層名との関係は豐比地区参照。償式地は本別

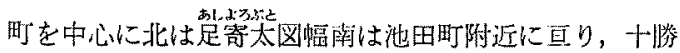
平野に広く分布する新第三系上部層である。下から本別 層と池田層に分ける。[備考］本層群の模式屬领は下加 ら本別層・哫等層・池田層である。足寄層は足奇層图幅 に発達し 5 閶に分けられているが，本別図幅では分尿困

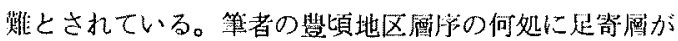
入るかは疑問として残った。[厥原］ $950 \mathrm{~m}+。$

i) 本別㖤

1953 本別趋群 位々保雄253

1955 本別層群 橋本 亘 ${ }^{9}$

[模式地］本別町東方。賽荖路層模式地の下流本別川 沿岸。[分布]川上層群の西側に又富岡背斜軸部に南北 方向に分布する。[岩相] 模式地附近ては下加蝶涪層 と橉牛屏とに 2 分さ扟る。稲牛尿は模式地のすく南で池

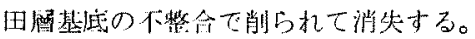

螺湾履

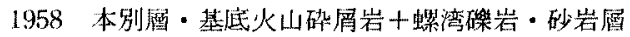
谷滕利( 小 $^{(0)}$

1959 同上 三谷勝利ほが

模式地から南へ活平附近迄は爍岩・砂岩・タフを主と し带緑灰色シルト岩を伴なうが，富岡背斜地带では上部 が砂岩で下はシルト岩で下限は露出していない。模式地 では古期岩類（黑色粘板岩・黑色砂岩・各色チャート） の円磂を含有する碟岩を基底とし，含碟シルト岩を少し 㷋んで再び厚い啋岩が発達, 最上部は浮石質夕フ質砂 岩。この抄岩に袹炭片を含んで来て䅺牛属に移行する。 保岩は螺湾保岩と呼ばれ本別町北方に発洤するが，本別 沚以南では念激に砧岩・シルト岩相に变化する。[化不] 本別化石带の模式地であり，多くの只・有孔出化石が 1/5 万本別図幅 ${ }^{11}$ で報告されている。代表種 Fortipecten takahashii YoK. は活平附近, 池田町東方ヶネーシツ川, 豊頃村豐頃背斜北力沈降部に発見されている。理藻化石 はケネベッ川で採取しれ4試料には全然含まれていず, 対比出来ない。[下位層との関係］不整合。模式地加

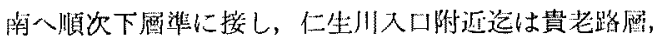

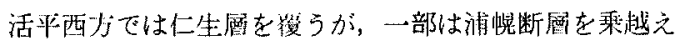

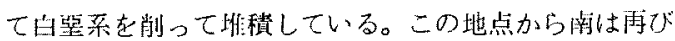

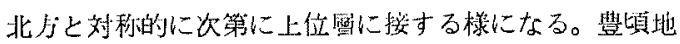
区のノヤウシ層基宾は平行不整合であるが，本別地区で は傾斜不整合で西る。[圓厚］ $330 \mathrm{~m} \pm 。[$ 備考］文献

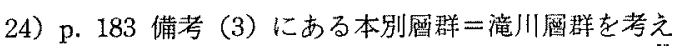
る時, 筆者は文献 66) と同しく澺川圆群二潼川層十美 檴特層とし，下位の滰川層相当尿に本別層という名称を 与えたい。併しこの場合螺湾層下限が美䐑牛層下限に相

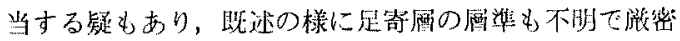
な刘此や定羳は今後の資料の增㧈に亦ったい。 


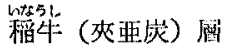

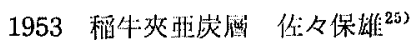

\begin{tabular}{|c|c|c|}
\hline 1955 & "I & 橋本 亘.9 \\
\hline 1958 & $\prime \prime$ & 三谷勝利ほか, ${ }^{10)}$ \\
\hline
\end{tabular}

本別川東方モップ沢を模式地とし本別川以北に分布す

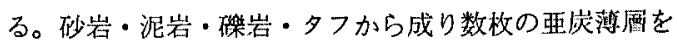
夾む。全層を通じタフ相が卓越し，本別町附近では殆ど タフ質砂岩から成り, 偽層発達, 又亜炭片を多数含む。 模式地附近の泥岩層に双子葉化石がかなり含ま机る。下 位層とは整合渐移。層厚 $0 \sim 30 \mathrm{~m} \pm 。$

ii）池田屬

1932 池田層 大不三郎・没辺武男2

1933 池田層 根本忠筧ほか。

1959 池田層 三谷勝利ほが ${ }^{11}$

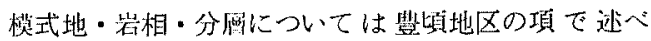

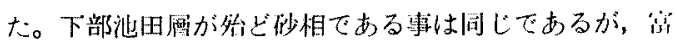

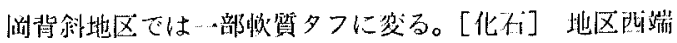

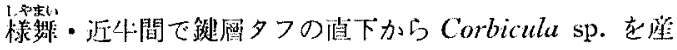
する。[下位層との関係］平行不整合と見られる。[酋 厚]下部 $220 \sim 300 \mathrm{~m}$ 。上部 $330 \mathrm{~m}+$ 。

\section{D. 浦煶断層以東}

釧路炭田西部の浦幌炭田地区である。十勝平野地域と は別な構造区に属すると筆者は考えている。比較の意味 で簡篻に屡序を記述する。

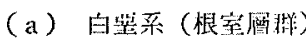

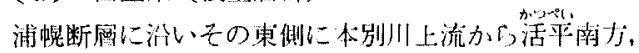
及び留岇ドーム・浦嘎背斜老形成して分们する。本别・

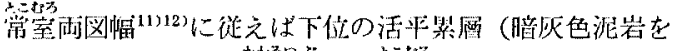

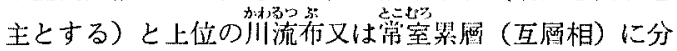
れるが，注目すべきは浦輓断層側に，より下位の層があ る事である。時代はへトナイ伳。下位層との関係は最下 位が浦棍断屏に接していて不明。

(b) 古第三系

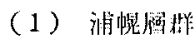

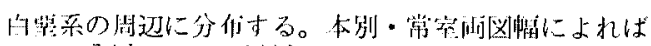

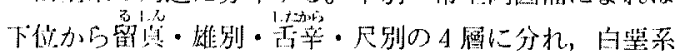
とは微傾斜不整合関係である。而して本層群は炭田の中 蚰部に比较して酉へ向う程薄化・粗粒化する傾向が特徽 であるとされている（文献 12） p. 8，9）。酋厚は最大 $650 \mathrm{~m}$ と云われる。時代は浙新圤で最下位だけは始新怛

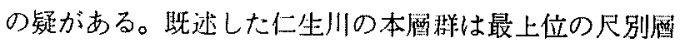
てある。

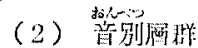

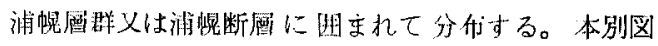
幅"1て舆本別層と呼ばれその説明は既に述へた。下位の
浦幌層群を微傾斜不整合に得うが，浦沅断層側（西側） へその倾侴不整合の割合が增大する（文献 12）p. 15) のは上記浦沅層群の堆棈盆地の西側に，本層群の盆找如; 移動したと解せられる。層厚は最大 $850 \mathrm{~m}$ とされてい る。

\section{E. 火成岩類}

䇺頃山地及び日方川に露忚する。

（a）基盤岩に関係あるもの

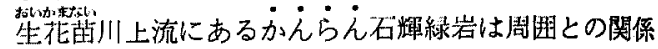
は不明である併し日高带で輝緑凝成岩が全北海道的に 見られるので一応基盤岩（豊頃層=空知層群？）のもの と考える。

（b）中里層の火山岩類 ${ }^{83)}$

流紋岩 玄武岩質の熔岩・集塊岩・㠜欧（角磷）岩等 から成り，陫積岩を介在して複䊒であるが（流紋岩質） 線色解保岩 $\rightarrow$ 安山岩質乃至玄武岩質熔岩・集塊岩の順

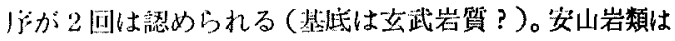
領下で解石等が多く見ら机変朽桨山岩化し, 所謂グリ ーンタフ地域に見られる岩石に近いのは眖㕱ある事実で ある。

(c) 脈岩類 ${ }^{83)}$

生花苗層迄賴いて，流紋岩～玄武岩脈が丸山三角点 大川・当緣山等に小さく出ている。三角点大川 $(308.7$ $\mathrm{m})$ の北方で，豊頃層と中部生花苗層が東西方向の断層 で接する筒所に玄武岩脈があるほかには，地質棈造と直 接関係する脈岩は無い。併し脈岩類の分布は基盤岩䈃出 腑近に限られている事は父張り構造と関係しているのか 为知孔ない。

(d) コメンド岩"

$1 / 10$ 万大樹図幅 ${ }^{4)}$ に説明を变る。忠類部落北方の山を 形成している。

(e) 玢岩"

説明は $1 / 10$ 万大樹図幅に詳述してある。日方川・中 八川で，日方川層・中ノ川層に夾まれて簬出している。

\section{IV. 対比及ひ微化石}

IIIて述へてて来た各地区の刘比を行うと共に，その根扬 の1つとなった微化石内容を逨へ，推栍環境の推定及び 北海道中軸带（油田が成立しており，圆序が最も研究さ れていて基準となっている所）との対比を行う。

\section{A. 対 比}

书沅断層以東と本別地区との古第三系の対比につい は, 岩相も類似していて距離も近いので $1 / 5$ 万本別・篣

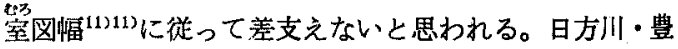
缇・本別地区の対比は次の順序で組立てた。

(a) 岩相による対比 
第 3 図標準層部化石刘比図

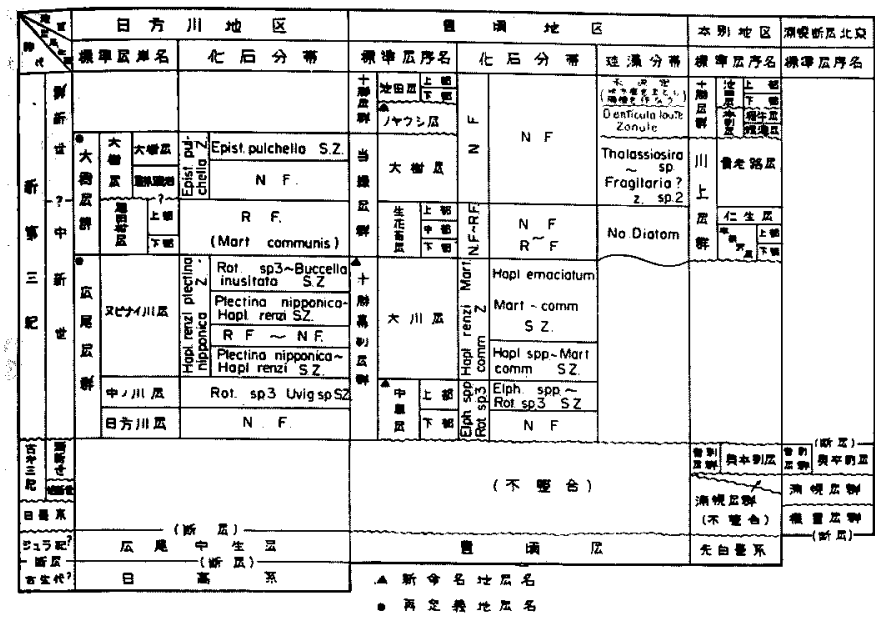

第 1 裴 有孔出による刘比

\begin{tabular}{|c|c|c|c|c|c|c|c|}
\hline \multicolumn{2}{|r|}{ 日方归区 } & \multicolumn{3}{|r|}{ 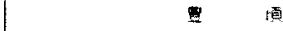 } & 加 & \multirow[b]{2}{*}{ 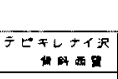 } & \multirow[b]{2}{*}{ 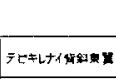 } \\
\hline s. & 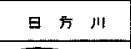 & कa & $\star$ & 学壮上 & 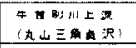 & & \\
\hline $\begin{array}{l}* \\
* \\
*\end{array}$ & - & t & & & H.F & & $\Leftrightarrow z$ \\
\hline 最 & $N F-R F$ & 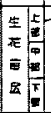 & $N \varepsilon$ & & HF - OF & $M F$ & Fion so ${ }^{2}$ \\
\hline 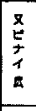 & 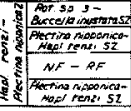 & $\begin{array}{l} \\
\text { in } \\
\text { 层 }\end{array}$ & $\begin{array}{r}\text { Hapt renzi } \\
\text { mare communis } \\
\text { 2ondere }\end{array}$ & 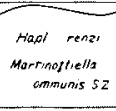 & 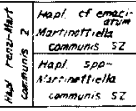 & HF - Pf & \\
\hline ? & $\begin{array}{l}\text { Avaria sou- } \\
\text { ungerina :o }\end{array}$ & 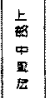 & & 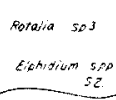 & $\begin{array}{l}\text { Elatidion Ito } \\
\text { Reraito sp } 3\end{array}$ & & \\
\hline 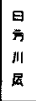 & & 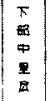 & & & & & \\
\hline
\end{tabular}

特徴的な岩相とその順序とを組合わす。即ち上から(1)

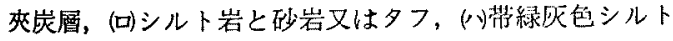
岩，〔硬質頁岩を主とする岩相，付于ョコレート色北

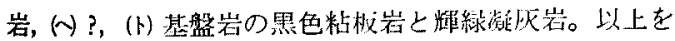

\begin{tabular}{|c|c|c|c|}
\hline & 日方川地区 & 嶄填地 区 & 本別地区 \\
\hline (1) & & 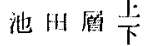 & 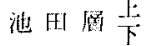 \\
\hline (घ) & & ノヤウシ層 & 本 別 層 \\
\hline$(y)$ & 大樹 層 & 大 樹 尿 & 貣 老路虞 \\
\hline$\Leftrightarrow$ & 尾 田村層 & 生 花苗層 & $\begin{array}{l}\text { 保生 䚛 } \\
\text { 别沢 }\end{array}$ \\
\hline 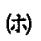 & ヌピナイ川層 & 大川尿上 & \\
\hline$(-)$ & $\begin{array}{l}\text { (中川愿) } \\
\text { (日方川尿) }\end{array}$ & （妕里 原） & \\
\hline (1) & （広尾中生層） & 豊 頃 畨 & 先白瑟秋 \\
\hline
\end{tabular}

掂べると左欄下うう表の様になる。裴を （）を付けた盧は独自の岩相を持ち対 比出来ない畨である。

(b) 有孔虫による対比

第 1 表の様になり， ヌピナイ川層と大 川層上下が，中ノ川層と上部中里層と对 比出来る事が判る。铤って広尾屏群と十

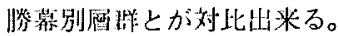

(c) 球藻と Fortipecten takahashii による対比

新田牧場の沢・茂岩西方ルート及び池 田町東方ケネベッ沢・午弗川の珄藻を 綜合すると(1)淡水型を主に海裂型を俳

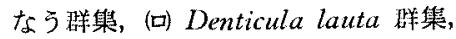

(v) Thallasiosira sp. $\sim$ Fragilaria? sp. 2 群集の化石皤学が見られる。本 别地区の本别期からは球漟老見ていな

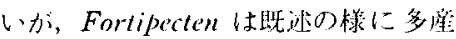
するので，己と組余すと

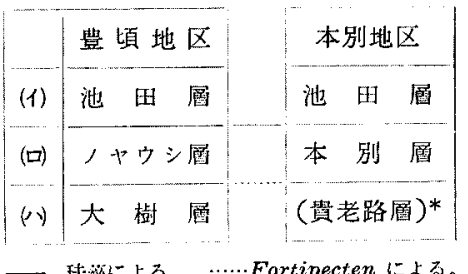

*頃老路原のH湢調盉は行わ扎ていな い。

（d）以上を綡合して次の衣力組主 てられる。

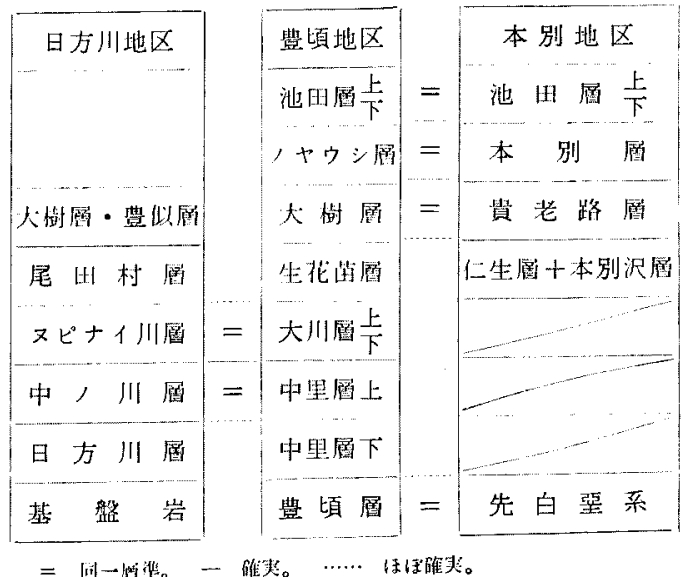

(e) 残った問題 
（1）日方川曆（タフ質砂岩）と中里層下部（緑色凝 以岩層）とは層の順序からは対比出来る椂でもあるが， 新第三系の整合する各層の間に夾末れていて対比出来る 場合と這い，基盤岩の上に来る基底相相互の遠距離間の 対比には疑問が残る。例えば日力川風も中里㳡上部相当 層であり，中里層下部は更にその下の涌滩であるとされ ても页定する材料はない。

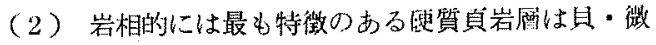
化石にきしく対比の古生物学証找がな。併し逆に云え ば化石の少ないのが特街とも云える。小村精—47》は珪藻 藻化石調查の折，等花苗尿は然理藻であるが放散虫は多 いと報じているので，将来は之による対比が可能になる 加も知れない。

（3）尾田村層と䇺似尿 -大樹層上生北苗層との関係 については楽に IIL B (2) iv) て述へた通り対比上の疑 問が多い。

\section{B. 微化石内容亡環境考察}

(a) 微化石内容

各地区の徴化石内容は第 2 表〜第 5 表の通りである*。

この表は上記で対比した 地層区分毎に䋚めてあるの で，対比の結論が出た後て整理した形になったが，そう てはない。方法論的には, 先ず層序記载の項で化石内容 を示し，之をも基にして対比論に移るべきである事が当 然である。本稿の実際の检討順序も試料採取地点と地層 との関係及び，化石内容の帘化（化石層序）上地層岩相 (序序)と在﨎応させつつ組立てたのである。今この栐

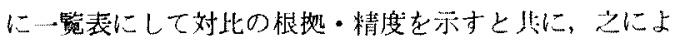
る倠皘摆境の提定を行ってみた。

(b) 堆積環㑽の考察

(1) 中八川罒・中里屈上部

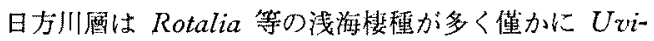
gerina が認められ，浮遊性種を伴なうので outer neritic 位の海流の影響のある所に推樍し, 幽首別川上流（中里 層模式地）では Elphidiumが多く見られるので inner neritic〜littoral 罢境，当縁川上流は雨者の中間噮境と考 えられる。之等を㳭い順に菲へると日为川・当紋川上 流・愔首別川上流となる。

\section{(2) ヌビナイ川呞・大川原}

大部分が砂翼種て石灰質锺が少ないので，堆積裳境推 定は困難である。日力川層の下部は殆ど仯質種から成る が，Uvigerina と浮逰性種を怑なうので海流の影㢸のあ る upper bathyal 位に堆積し，上部はEllipsonodosaria， Bolivina, Uvigerina 等の比較的深海楼の種に浮遊性の 種が伴。ているが，大部分の石灰質種は浅海嬠 Rotalia

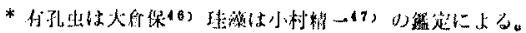

で占められているので幾分浅くなり outer neritic 位に 堆積したと思われる。牛首別川（大川屬模式地）で㫾 質種が大部分で，僅かに Rotalia 等の石灰質種が槷めら れる。石灰質種から littoral 位の環境を考えたい。忠類 果南方・当緣川で砂貿種のみであるのて，日方川と午 当別川の中間位の演水性の場洌に堆積したと考える。滐 い順に䨿へると日方川尿下部・上部・忠類東南方と当緣 川・牛首別川となり，前記（1）と同し順となる。

\section{(3) 尾田村層・生花苚圈}

日方川では Martinottiella communis d'ORB. のみて ある。テピキレナイ沢東のテと゚キレナイ背斜軸部の中部 生花苗盗ではRotalia が大部分である。牛首別川上流で は下部が浅海棲種上部に沙诈種が僅かに想められる。全 域に亘りほぼ inner neritic〜littoral 環境に堆積したの ではないかと推定する。

\section{(4) 大樹覤}

慬加 Globigerina spp., Epistominella pulchella

第 2 表 中ノ川層及び上部中里層の有孔虫内容

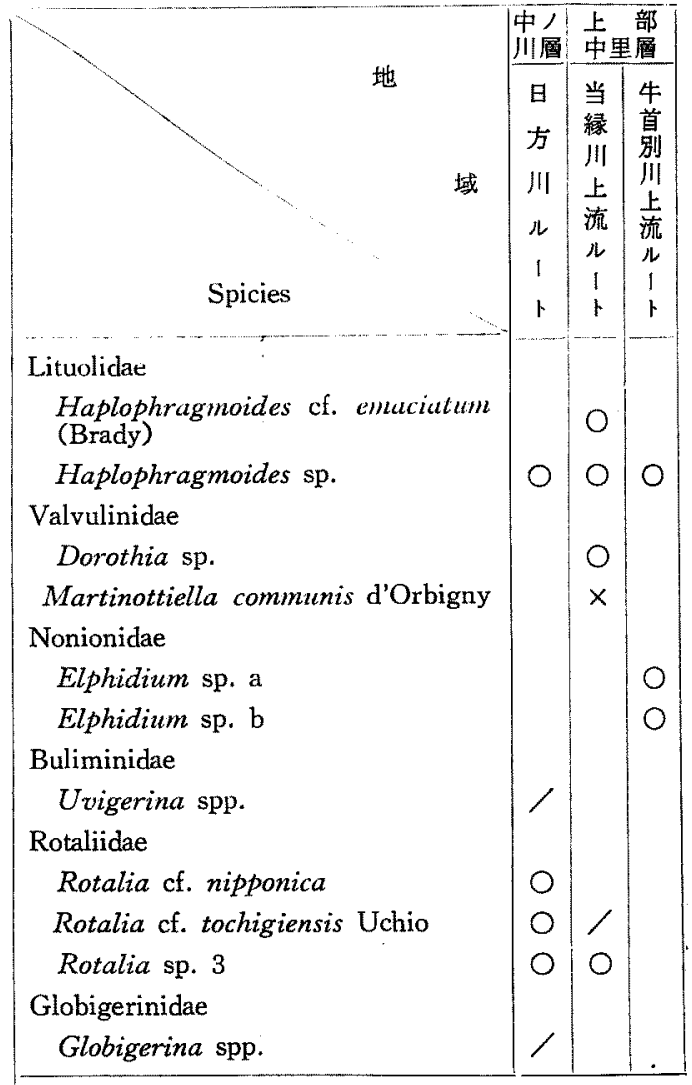

凡例

都珰は微化石個体数を表わす。以下同じ。 $x \cdots 1 / \cdots 2-5 \bigcirc \cdots 6-20 \bigcirc \cdots 21-300$ 
第 3 表 ヌビナ1層及び大川層の有孔出内容

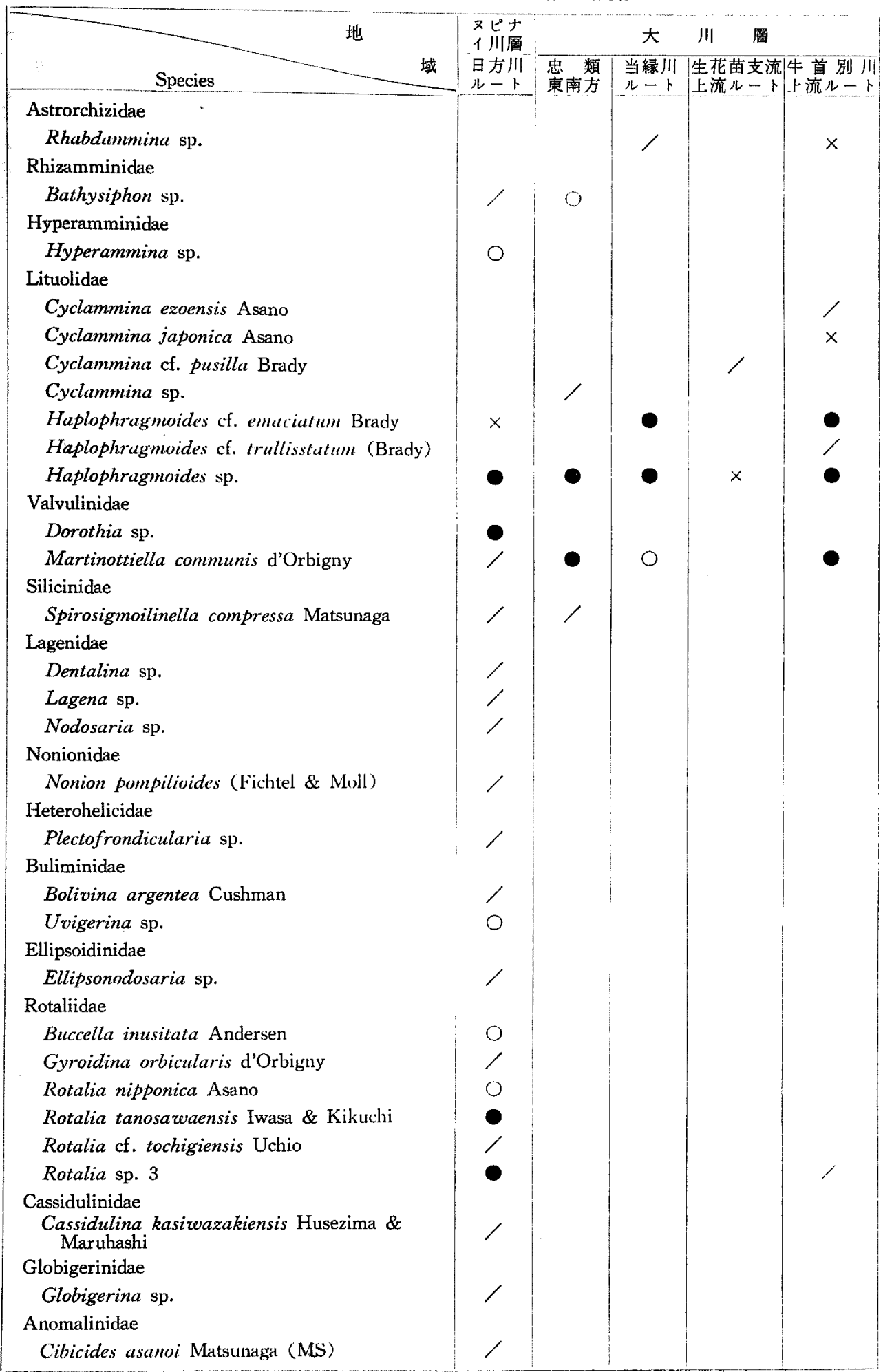


第 4 表 尾田村層及び生花背層の有孔出の内容

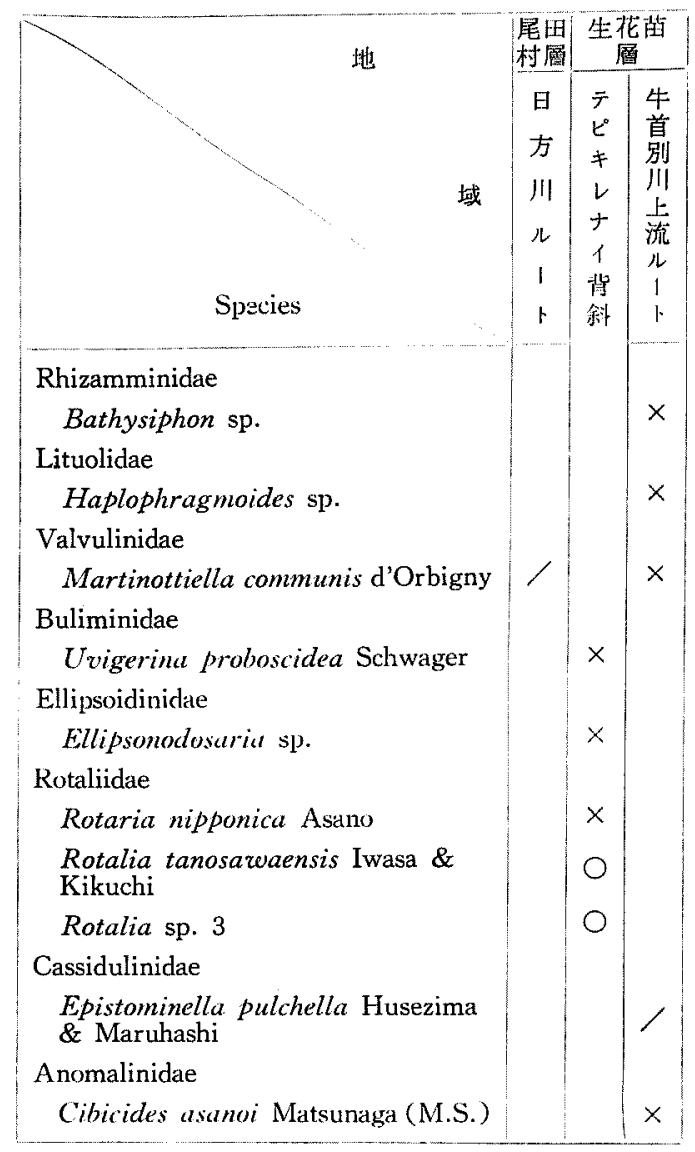

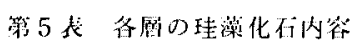

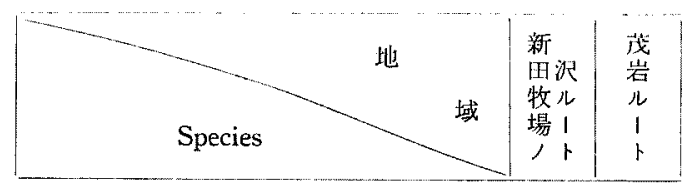

Taiki Formation; Fragilaria? sp. 2.-Thalossiosira sp. Zonule

Family Coscinodiscaceae

Stephanodiscus sp.

C'oscinodiscus excentricus Ehrenberg

Coscinodiscus oculus-iridus

Ehrenberg

Coscinodiscus stellaris Roper

Actinoptychus senarius (Ehrenberg)

Family Thalassiosiraceae

Thalassiosira sp.

Family Rhizosoleniaceae

Rhizosolenia hebetata var. subacuta Grunow

Family Biddulphiaceae

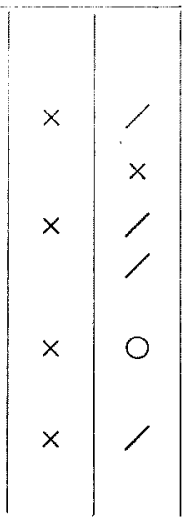

Biddulphia aurita Brebisson

Biddulphia sp. 2.

Family Fragilaria

Fragilaria sp. 1.

Fragilaria sp. 2.

Family Acnanthaceae

Cocconeis sp. 3.

Family Epithemiaceae

Denticula lauta Bailey

Subtribe Pyxilleae

Dicladia cfr. pylea Hanna \& Grant

Xanthiopyxis spp.

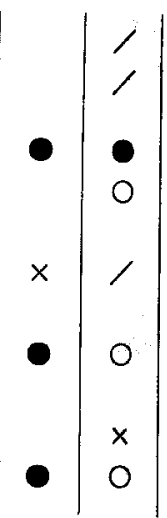

Noyaushi Formation: Denticula lauta Zonule

Family Cosinodiscaceae Stephanodiscus sp.

Family Melosiraceae Melosira sulcata (Ehrenberg)

Family Fragilariaceae

Fragilaria sp. 1.

Fragilaria sp.

Family Acnanthaceae

Cocconeis sp. 3.

Family Epithemiaceae

Denticula lauta Bailey

Subtribe Pyxilleae

Xanthiopyxis spp.

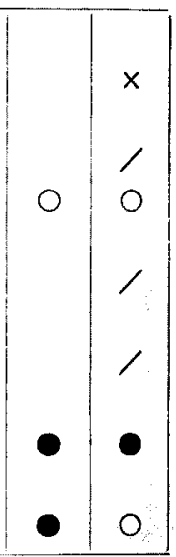

Upper Ikeda Formation: Diploneis sp.

a.-Navicula sp. a. Faunule

Lower Ikeda Formation: P.D.

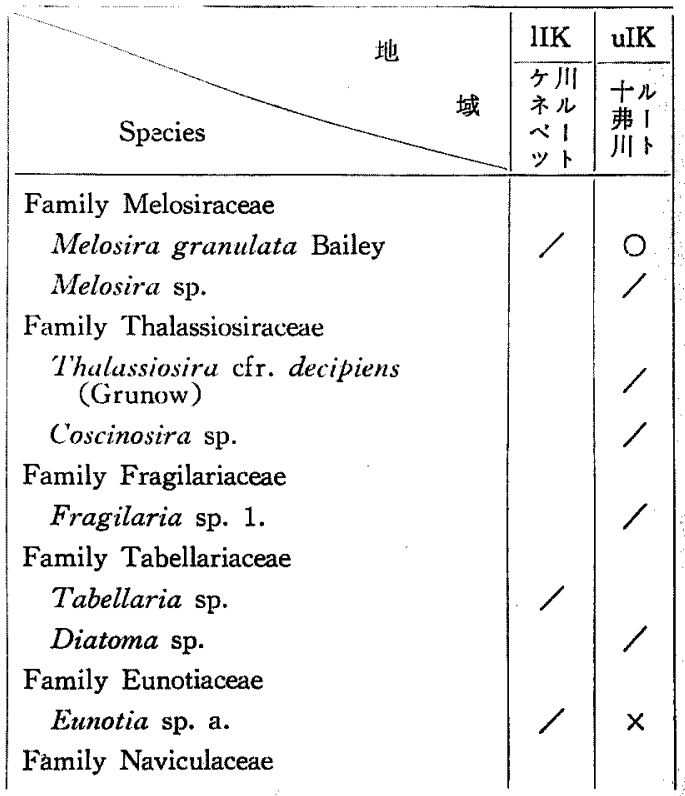




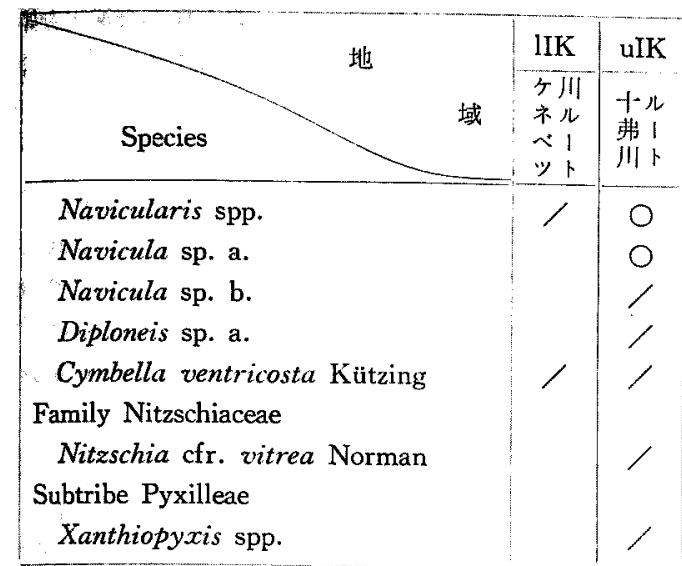

HuSEZIMA et MAROHASHI, Buccella inusitata ANDERSEN, Cribroelphidium yabei (ASANO), Urigerina sp,. $U$. subperegrina CUSHMAN et KIEINPELI を産する。 恐らく neritic zone 位に惟積したものてむ万う。

\section{C. 北海道中軸帯との対比}

(a) 墔藻による対比

1959 年小村精一 ${ }^{50)}$ は石狩・日高问地区にかけて理落化

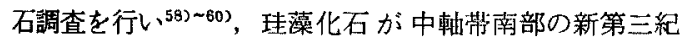
層対比に極めてょく適用出来る事を発表した。理藻は浮 遊性である為対比に適しているのは当然とも云えるが， その後調查範囲を南北入㹡け北は留竝町の滰川層群分布

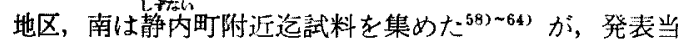

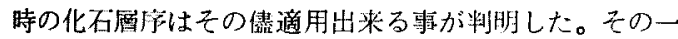

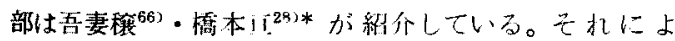
ればは Stephanogonia-Coscinodiscus (elegans forma)

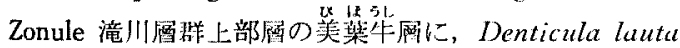
Zonule は潼川層の Fortipecten takahashii 動物群層望 に, Nitzschia-Thalasiosira-Fragilaria? sp. 2 Zonule は留萠層下部, 当別層下部・荷菜屈（旧萠別屈の上部）

$に$, Coscinodiscus elegans, C. marginatus Zonule は

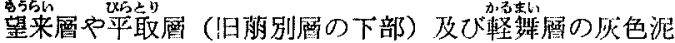

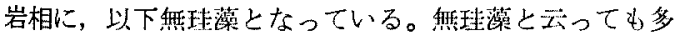
種産出法によるむのて，金個体を取出すう法を行っては

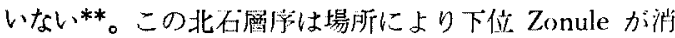
えるが，十勝平野地域もこの例となる。即ち NitzschiaThalasiosira-Fragilaria？ sp. 2 Z. の下は無珪㴪とな る。生花苗層かi N. D., 大樹層は Fragilaria？ sp. 2Thalassiosira Zonule, やウシ層は Denticula lauta Zonula となり，道中軸带と完全に対比出来る。池田原 は Zonule 名は未決定でるが，淡水種の Navicula， Molesira, Eunotia, Synedra, Cymbella, Gyrosigma t

*北淮道の地樭 2 s, 地下凅源 Np.9, p. 23 .

** 文嗝 66) p. 29 脚拄照.
主とし海婑種の Nitzschia，Thalassiosira を伴なう。道

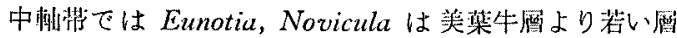
に多いので，ノヤウシ犀の上位の不整合が相当大きいも のか，或は十勝平野地域は中軸帯に较へてて早期に淡水環 境になったのかの何れかであうう。

(b) 有孔虫による対比

Haplophragmoides renzi-Martinottiella communis Zonule は日高地方の振老層の砂質群集と似る。即ち 又

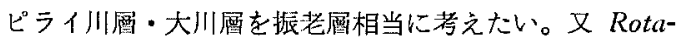
$l_{\text {ia }} \mathrm{sp.}$ 3-Elphidium spp. 又は Uvigerina sp. Zonule は滰ノ上層の Rotalia cfr. nipponica-R. tochigiensis Zonule の浅海壊境に似る。之により日方川層・中里層 を滰，上瓷に対比したい。[備考］ スピナイ川層上部に Rotalia sp. 3-Buccella inusitata 野带があるが，之に注 目して、ヌピナイ層以下を澢ノ上粕に対比する考えも

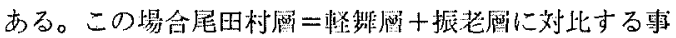

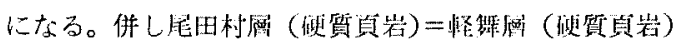

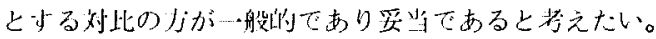

\section{V. ガス微よ油母岩}

地域内の油・ガス徽地の位㽞・層準・産出状況・棈造 との関係等を綜合検討し, 油母岩層の判定を行う。

\section{A. 油・ガス徴}

第 4 図に位置を示した。その露出番号順に(1)位置，(口)

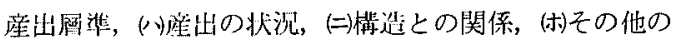
順に記す。

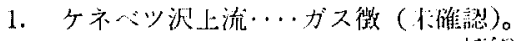

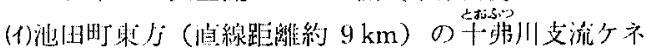

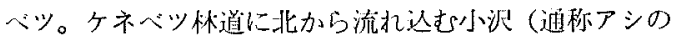

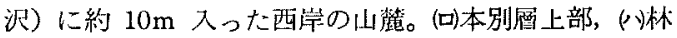
良和 ${ }^{36)}$ の報告による。1958 年替迄は硫化鉱泉と其に僅 かな可燃性ガスが出ていたとの村人の談である。に富岡 背斜檕部

2. 豐頃中学校…ガ行徽。

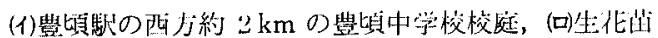

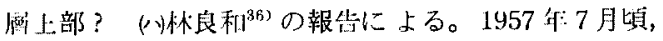

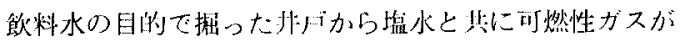
貲出した。哚度は $224 \mathrm{~m}$ 。 $\mathrm{Cl}^{-} 5,020 \mathrm{mg} / \mathrm{l}$ 。(豐䐜背斜 檕淤近。

3. 常国石油構造試錐…ガス徽

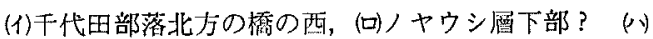
㳭度 $500 \mathrm{~m}$ 。坑底近くからガス貲出。ガス量最大 4,000 $\mathrm{m}^{3} / \mathrm{d}$, 水は $300 \sim 400 \mathrm{~m}^{3} / \mathrm{d}_{\text {。 }} \Leftrightarrow$ 千代田背斜軸部附近。

4. 一代田小学校…ガス应出。

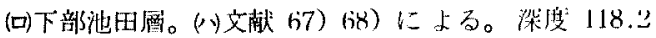
m。力＼cjkstart量 $76.0 \mathrm{~m}^{3} / \mathrm{d}$, , Cl-2, $059 \mathrm{mg} / l_{\mathrm{o}}$ GWR $1: 2.8$ 。 
第4図構造図及び先新第三系分布図，油・ガス分布図

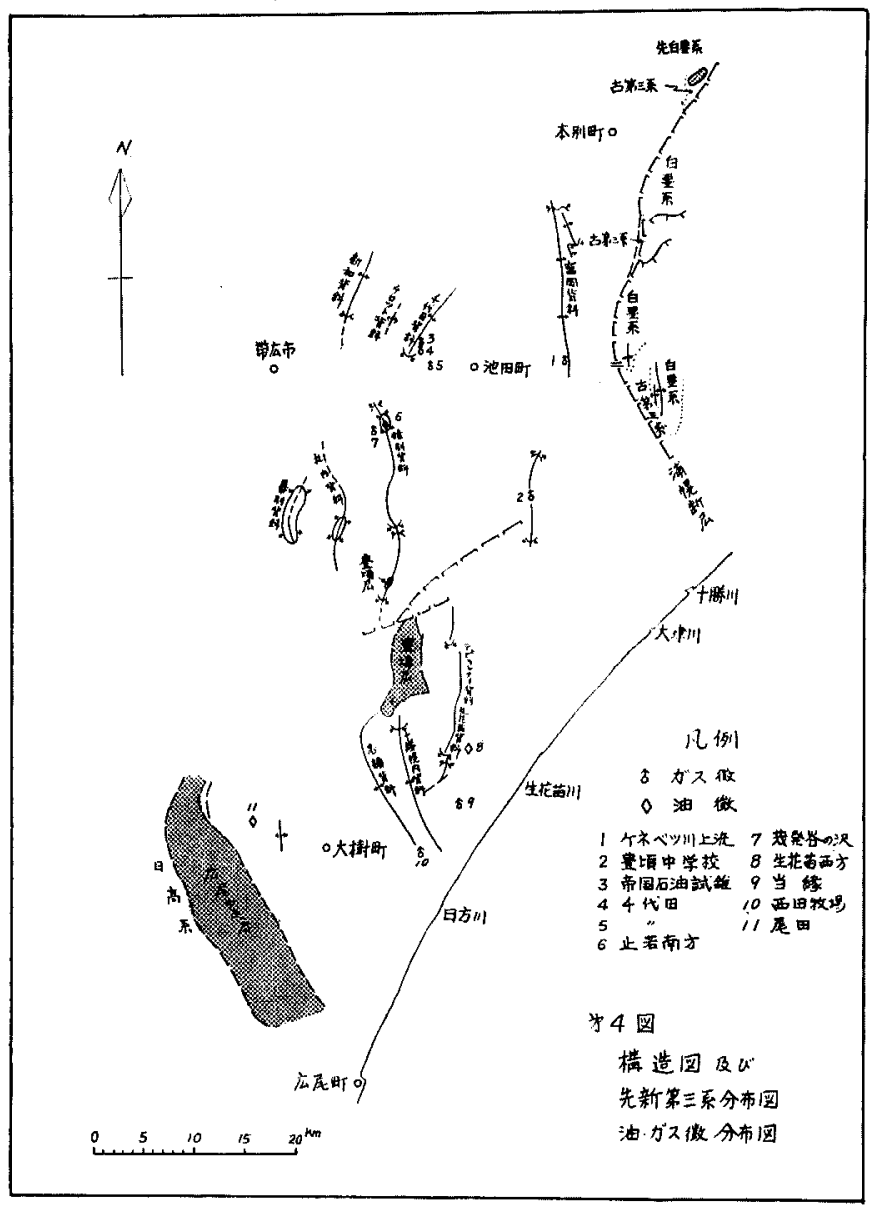

の砂岩と裂か部に油臭と僅かな渗出を伴 っている。(二猿別背斜の 1 極隆部の軸付 近。

\section{7. 茂発谷の沢…ガス徽}

(1) 上記油徴の西。茂発谷に入る沢入口 加約 $1 \mathrm{~km}$ 西へ入った地点，(吅池田首 鍵䚄夕フかその臬上，(冰田中に可燃性 ガス涌出。分析結果はメタン $85.56 \%$ ， 窒菜 $14.3 \%$ ，炭酸ガス $0.14 \%$ ，(二向斜 軸付近。

8. 热尘花苗西方…油徵

(1)生花苗部落から当緑へ抜ける道路の 最初の橋から約 $900 \mathrm{~m}$ 西に入った地点, (口)大樹原，(ソ正谷清 ${ }^{34)}$ 等が発見。止若の 油徽と同模に，大樹層の成色泥岩の割目 に油臭がある，(二生化䏴背斜軸から相当 離九た東翼部

9. 当縁…ガス徵

(1)上記道路沿いに南下して晚成の西， 水準点 51.77 と 52.16 の中間の沢。道 路から約 $300 \mathrm{~m}$ 入った沢の湿地带，(只上 部生花苗層で碟岩の発達する部分, 6 怇 底の湿地の泥から可燃性ガスと塩水が出 ている。塩分は $2,473 \mathrm{mg} / l_{\text {。 }} \Leftrightarrow$ 甡花苗 西方の油徴と同様, 背斜の東翼, (价島田 忠夫 ${ }^{15)}$ の当縁油徵と同一地点であると思 われる。囟田によれば湿地带の面積約 $50 \mathrm{~m}^{2}$ の地域に目測して発生量 $0.5 \sim 1$ $\mathrm{m}^{3} / \mathrm{d}$ 程度の微量ガスが認められるとあ

(二)千代田背斜軸部附近。

5. 千代田附近…ガス産出

(1)文献 67）に多数の坑抖が報ぜられているが，四て はガスの出る南限を示した。(口)下部池田層, (㳭度 91.0 $\mathrm{m}$ 。ガス量 $11.7 \mathrm{~m}^{3} / \mathrm{d}, \mathrm{Cl}^{-} 773.0$ 。 GWR, 1:4.5, $\Leftrightarrow$ 干代田背斜軘から僅かに離㧈た来桨。(1)干代田の民家の ガス斗は水溶性で $\mathrm{Cl}$ 相関留である。

6. 止若献为...油街

(1)止若付近鉄橋から南に直楾にして $2.5 \mathrm{~km}$ 上流の獾

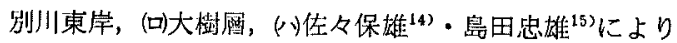
報ぜられた。佐々によれば带広市栄藤周蔵発見。參出油 は濃暗灰色。油砂は一般に5 7 cm の厚さであるが時 に $2 \mathrm{~cm}$ 或は $9 \mathrm{~cm}$ と変化する。油臭著しく水中に投 ずればギラを発し手に取れば暗蝎色粘調質の油気を付着 させる。同様なものが整て西觜にもあった由とある。島 田によれば $20 \mathrm{~cm}$ 前後の不烧則なレンズの夾みの中の盽

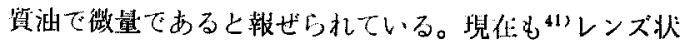

る。現在でもこのガスは文献 44）により認められてい る。

10. 西田牧場…ガス徵

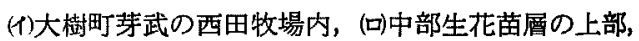
(壮河岸段丘堆䅡物の崩れで出来ている川床からガス噴 出。一番盛に出ている穴（直径 $9 \mathrm{~mm}$ ) は点火すると約 $15 \mathrm{~cm}$ の焰を上げて連続的にガスが然䙺する $\left(3 \mathrm{~m}^{3} / \mathrm{d}\right)$ 。 又當て防空境を掘った際付近の山地から滲出油があった との情報む得たとある。そして島田はこのガスの由来に つき石油系であり断層面に沿って出て来たものであろう と推定している。(忠類背斜軸部

11. 尾田…油臭

模式地の尾田村屬でハンマーで硬質頁岩を吒くと油臭 がする。棈造上の位置は東落ち単斜である。

以上を絓めると次表になる(次頁の表)。

\section{B. 油母岩の判定}

（a）池田層のガス焦は水溶性であり，大䙺模な産出 


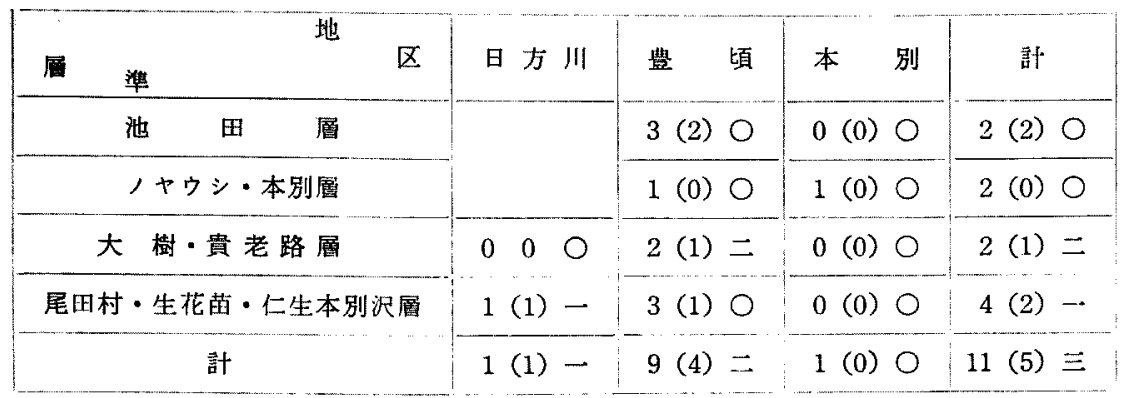

* 各行の 1 番左が油・ガス徽釉数。真中の（）内は背斜搆造に関保ないるの。右の日本数字は油数。

は望めない。貯留岩としては良好な岩相である。

（b）ノヤウシ屬のガス徵で坑排のものは対比上確実 にノヤウシ層である証抛がない。他の1つは小規模であ る。ノヤウシ層及び同層相当層は一般的岩相から見れば (释験的な肉眼観察) 油母岩となり得る岩質は少ない。 密ろ賖溜岩相としての粗粒岩が多い。

（c）大樹層中には構造に関連した位置以外にも確䒠 な油徽がある。特に構造に無関係で空吵部（割目）に徴 候が存在する事は，この層が母岩である事を示すと判断 される。ただ貯溜岩の存否の点では本層中の化は一般に $10 \mathrm{~cm}$ 以下の事が多いのて，地表資料からは悲観的にも 思える。併し油母岩の発達状況は地表瓷料から判断して 予想と異った例は余りないが，瞻溜岩の任否は必ずしも 地表資料から判断される通りだとは限らない。例之ば石

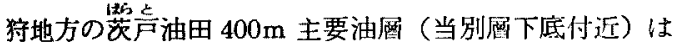
層厚 $3.30 \mathrm{~m}$ あるが，地表に露出する当別層下部と比較 すると岩相が異っている。油田地帯てはシルト宕・細粒 砂岩互層中に油層があるが，地表（石狩・知津狩油田地 域で分布する所）の相当層はシルト岩を主にするか, 全 体に粗くなって徵細粒砂岩を主とするかの何れかであ り，顕著な互層相は見られない。本互㖤と之に引統き堆 摃した当別層の厚さは，茨芹背斜の翼部から極隆部に近 つくと薄くなる事゙は II C (b)（2）『緑介した集油理 論に合致している。互愿相の発達とこの「惟樍当時の离 まり」という環境とがいかなる関連を持つかについては 末解決であるが，以上の様な奏例がある事を強調してお きたい。

（d）尾田村層及び相当層の油街も大樹層と同しく母 岩相である証拠と考える。北海道ではいわゆる板状硬質 頁岩層は発達が普徧的でかつ油徽も多い買準であり, 軽 箭・石狩油田の産油䚄にもなっている。従って岩相的に む層準的にも尾田村層相当痼は海岩として良好だと判断 出来る。因みに層準的類似は，同じ時代の層は或る程度 同樣な堆積環境下に堆積した為か，本邦油田の主な産油

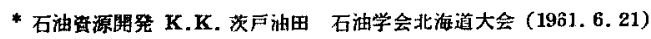
のハンフレット p. 10 11。
層は新第三系の中でも中新統上部を中心として集中して いるのは與味深い。日本鉱産誌 ${ }^{16)}$ p. 43〜44の表にもこ の事が明瞭に表加ている。

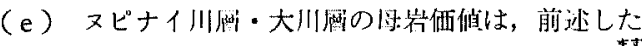
層準的見地加らは北海道での産油層集である层老層・増 㹸層にも相当し，又岩相的にも油母岩になり得ると（肉 眼的経験的からではあるが）見られる。併し現在迄に油 徵が知られていない事は，母岩としての条件が悪い為 か, 調査密度の小さい為か何れとも判断しにくい。

（f）日才川層・中里層は基底粗粒相で母岩にはなり 得ないと判断される。

\section{VI. 構 造}

\section{A. 背斜構造}

第 4 図に背斜名と位犆とを示した。背斜軸楾が非常に 長く連統しているものは，奏際には幾つかの極隆部があ って軖は滩行形をしていると思われるが，調查が未だ精 密でない為にこの様に示された。幕別背斜は地震探鉱で 存在が確認された構造であるが，十勝平野下には今後す 新しい背斜が胃出される可能性が残っている。

\section{B. 等重力線図と基盤岩・断屏}

等雷力線は基盤の分布をよく站わしていて，豐頃山地

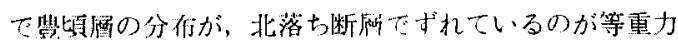
線が细実に亦さ机ている。そのてこの断圂の延長方向为 推定出来る。因名にこの北東東方向润切り断尊は南のブ

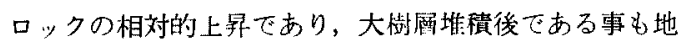
睤図て判読されるが，現在の当縁川と棣内川，又日方川 と柇内川㔖川間の分水嶺を形成した運動とその方向が一致し て扣りもっと新しい時代の（時代迄の?）断層加も知れ ない。又等重力線間隔が狭くなって続くZone には断屏 の存在が予想されるが，浦㹸断酋が明膫に表示されてい る。同し様な形が猿別背斜西翼にあるが，新第二系は切

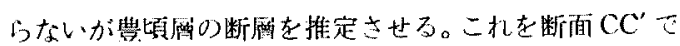
拯用した。（第 2 図参望）

\section{C. 浦幌断酋の意義について}

浦幌断層は前述した通り，第三系に根室層群 (白珐系) 
第 5 图䈔重力線と基盤岩及び断層との関係

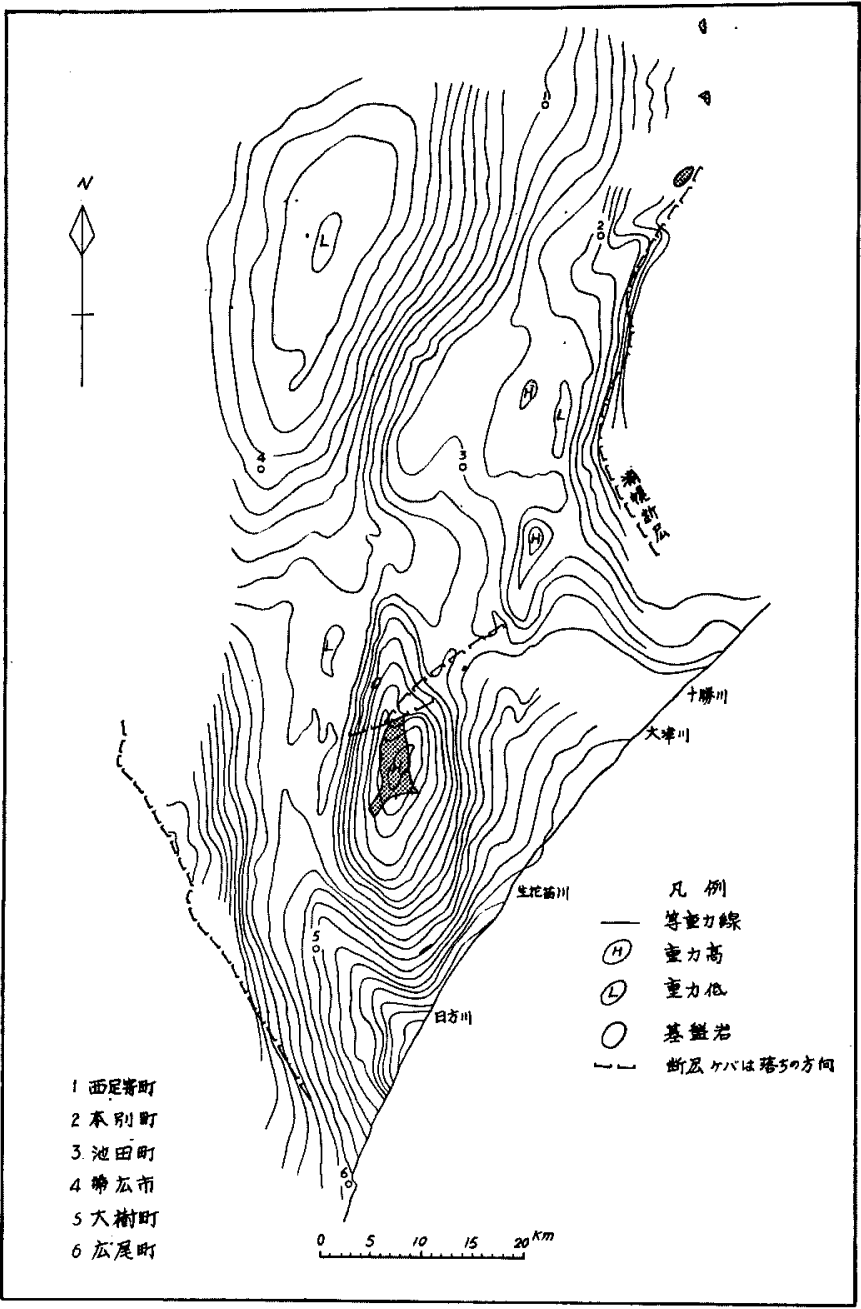

と新第三紀とでは上昇・沈降の動きが全 く逆になった事のある大きな基盤地塊わ 境界線である上解釈する。この事は古第 三系及び白裂系の堆積当時の分布並びに 現在の分疠（地表には露出せずに新第三 系分布地の地下に隠されて分布高る場合 を含むり）に対する推定の問題てあり，石 油地質的には十勝平野地域て之等の下位 偈準を対象々した石油探鉱を行い得るか 否かの問題で重要である（道東白垩系の 雇油可能性について最近資料が集まりつ つあるが，目:岩相の発達も良く貯溜岩相

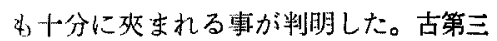
系は海成被の発蓬不十分と考えられるの で，産油の期待は余り持たれてはいな い)。浦坭断層に接する白卧系は堆積盆 地の縁辺相を示す証扰はないので，縁辺 部は断㞗の西側にある事と, 浦幌層群・ 音別層群は岩相から考えてその堆積盆地 の規模は余り大きくはなく，既述した梾 に浦幌首群は既に浦坭断尿付近で縁辺相 化しており，音別原群の崔積盆地はその 阿へ少しずれた形をとるであろうという 事を考鬼しつつ，浦䶃断缕の運動を顧る 上第 7 図の様になる。(1)は断層以西の日 方川地区迄の地域。(口)は浦幌断層以東の 浦幌炭田側である。

(a) 白堅系 (根室尿群) 堆稫時.... (1)(口)共に沈降。(1)の地域の西に白垩系の 緑辺相があった。

（b）浦棍尿群堆積時…( ( ) 上昇して しまい，白䜿系は剀制される。(口)に浦幅

のより下部が接している西落ちの大断尿である。この 断国を境として画侧では白瑟秀と古第三系の大部分は全

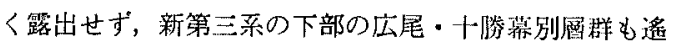

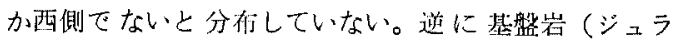
系?）は断呞果側ては趼出世ず*西側にのみ見られる。

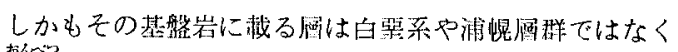
音別尿群以上の凰である。之等の関係は第 $4 \cdot 6$ 図に見 られる通りである。この事から篗者は浦猊断層は現在の 地冨の平面的分布を分けているだけてははなく，垂直的存 住をも分けている檴造線でありその意義は大きいと考え る。即ち浦帨断層を境にして十勝地区と道東白垩采地区 と橉造区が分れ，しか子この棈造線は白珰紀〜占第三紀
層群が堆積しその西限は傤幌断層の少し西部であった。

(c) 音別層群堆積時…⑴(听共に同前。(1)の白严系 はますます削られて，大部分は無くなったと思われる。 音別層群堆積の西限は（b）の時代より女少し西へ移動 する。

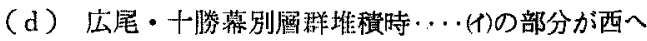
傾くが(口)は安定して堆積物がない。(1)側で䇺頃丘陵がや や上昇している事については堆稹盆地の考察の項で記 す。

（e）尾田村層 - 生花苗屬堆積時…(1)(听其に沈降。

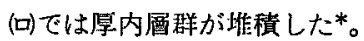

（f）ノヤウシ・本別属堆積時…堆積直前に浦幌断 

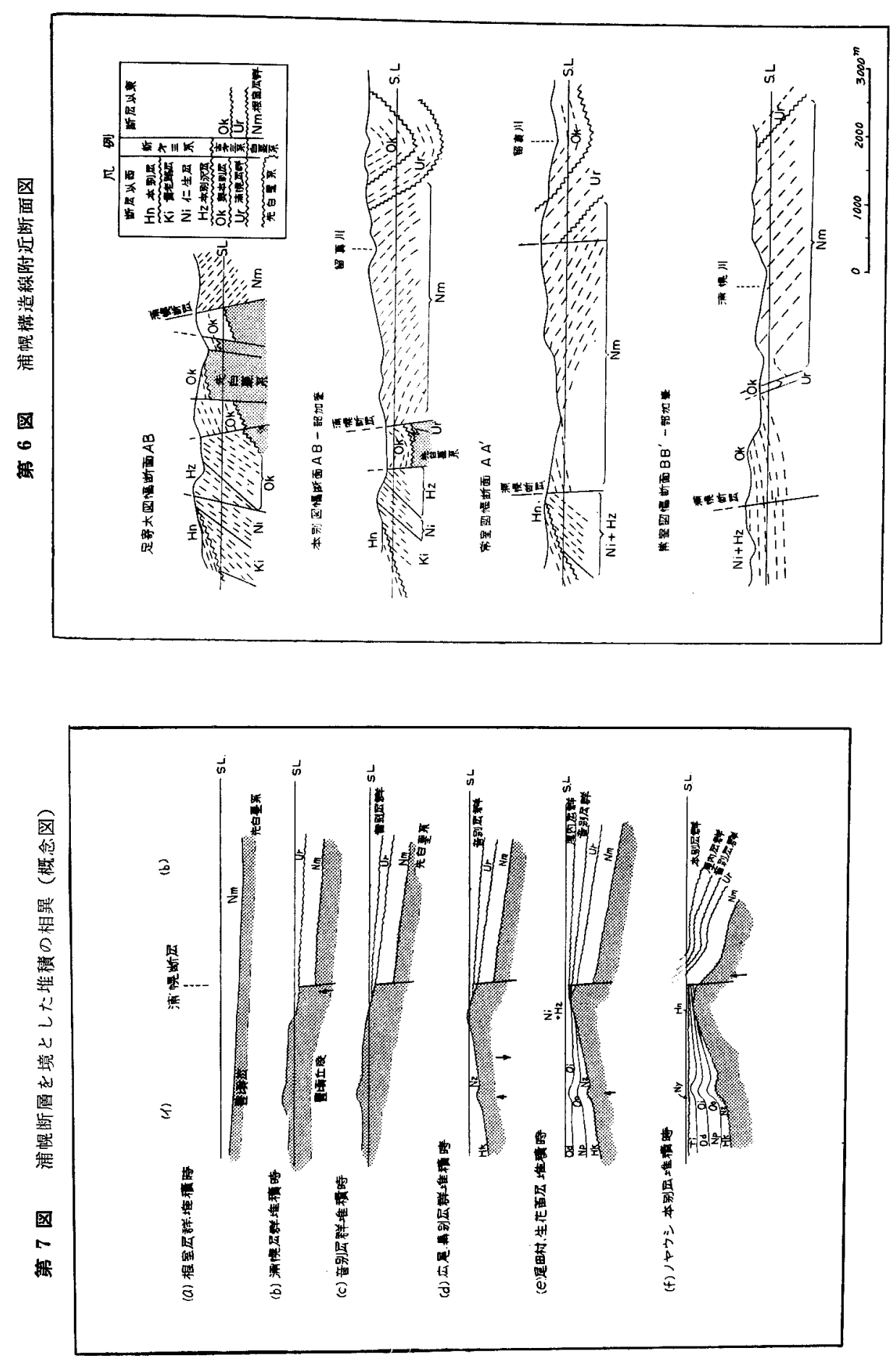
第 8 圆尾田村層・生花苗層等層擪線図と現在の背斜の関係

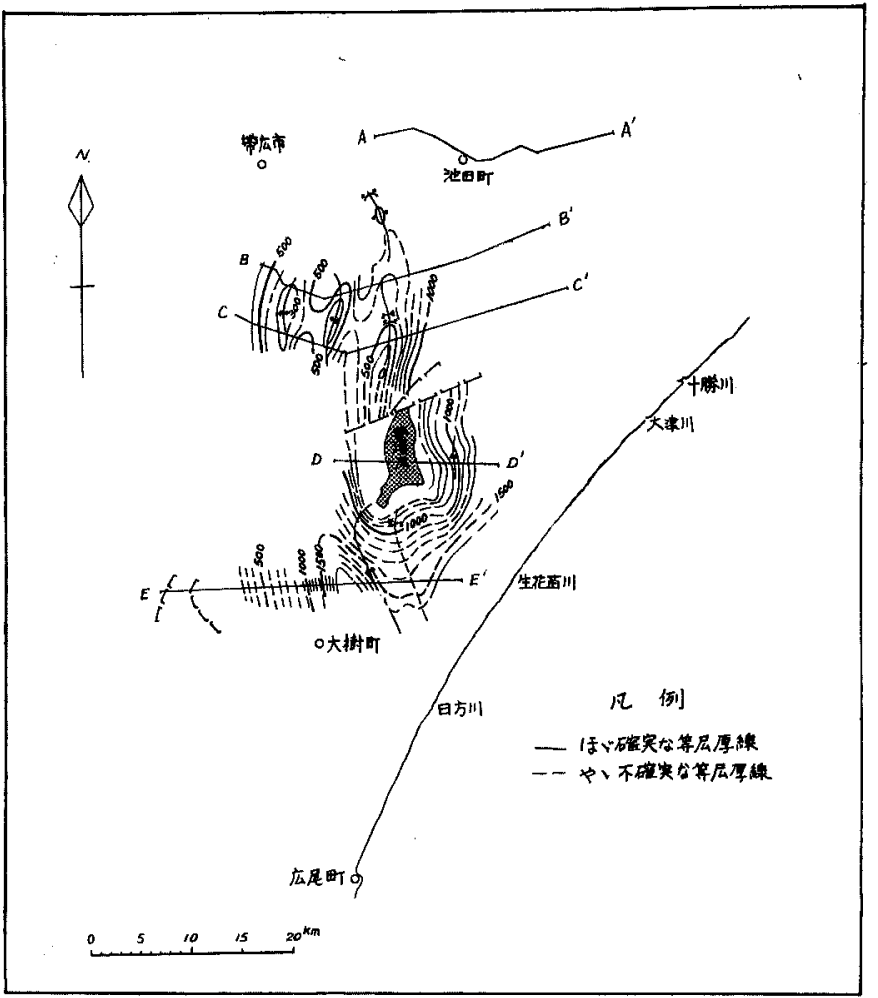

川地区では海流の影響のある所であり， 豊頃地区では豊頃層の分布に近つく程浅 い環境てあると推定出来た。この事は上 記の南へ開く事及び豊頃層が ridge を形 成している事とょく一致する。そこで尾 田村・生花苗層堆積当時の環境もそれ以 前に引統いたものであると見られる。

(d) 背斜軸と等層厚線図との一致.. . 猿別背斜系列及びその西側礼贺・幕別 両背斜では地層の薄い所と背斜冠部とが 一致している。然るに他の背斜ではこの 様な一致が見られない。油母岩である大

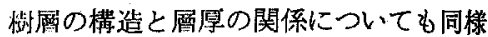
である。以上の事から， V B で判定し た油囦:岩の堆積盆地は凡て次の様に整理 される。(け)南へ開いた盆地である。(可豊 頃層及び猿別背斜系列を中軸として盆地 が東西に分れる。けりこの 2 分された堆䅡 盆地の西側（但し豊頃層分布䉇囲以南は 除く）は背斜構造と母岩の薄化している 所が一致しているので集油構造としては 最も良好な所である。[備考］層序記載 の項で猿別背斜の軸部及び两翼で池田層 の堆積袈境が異なる事を述べたが，豊頃

層が活動し，前とは逆に東側が上る。この断層運動が行 われた結果, 活平付近は陸化し，韻老路層や伦生層が削 剥された。その後で本別層が覆って堆積している。

この様に考朰たので, 渻者は十勝平野地域には白裂系 は存在しないか, あっても一部の削剩残部で石油探鉱の 対象にはなり得ないと判断する。

\section{VII. 堆積盈地の考察}

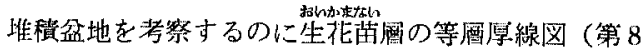
図）を取上げた。生北苗層を選んだ理由は目岩として適 当である為でるか，又資料も比校的数多く得られた為 でもある。但し本別地区は資料がミしいので除外してあ る。

（a）南へ開いた盆地である。…北と南とを比较す ると南側へ堆積量が增大する。

（b）豊頃層と猿別背斜系列とを中心として東西両側 に厚くなる。即ち豊頃尿は堆積当時から ridge を作って いたと判断される。えが第 7 図の们地区で豊頃丘陵を上 舁せさた理由である。

（c）有孔虫による惟皘環境の推定を IV B (b) で行 った際, 生花苗層は全域に亘りほぼinner neritic littoral の堆皘物であると考えたが，それ以前の各層は日方 ridge の上昇は池田層堆積時代にもあった事を示すと解 せられる。

\section{VIII. 構造発達史}

各項の記述に既に触れて来たので,ここでそれを悢め る。

A. 十勝平野地域には白㤠系及び 古第三系は発達せ す，浦幌断層はこの事実に対して重要な棈造線の役割を 持つと解せられる。

B. 豊比丘陵を構成する豐頃層の分布及び猿別背斜系 列は新第三系の堆積中に唯積盆地を 2 分し，その両側の

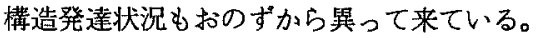

C. この2 分された西側の堆程盆地内において，その 北部の背斜は石油の移動集積には最も適した形成の歴六 を持っている。

\section{IX. 結論及び今啳の問題}

\section{A. 結 論}

（a）十勝平野地域の含油第三系層序の基礛がほほ確 立され，北海道中軸带の含泊第三系との対比む相当程度 判明した。

（b）本地域の石油探鉱の対象となる地層は，新第三 
系てあり，古第三系及び白垩系は地表地下共に殆ど存在 しないと判断される。

（c）堆積盆地の形が判明し，構造発達史の検討を加 れた合油構造の判定の基礎が出来た。

（d） 油母岩は大樹＝当縁＝川上層群及び以下と考之 られ，本地域は出油可能性が多いと判定した。貯溜岩は 上記各層中に含まれるものの他十勝層群最下部の粗粒岩 迄と考えられる。

（e）最む出油可能性の高いのは，猿別背斜の系列と その西側の背斜群であるが，東側の堆積盈地内は資料が そしく(特に地震探鉱) 判定する事が出来ない。

\section{B. 今後の問題}

今迄記述して来たものは，出来得る限り確実な資料た けを採用して，その篹围内で整理検討を行う様に努めた が、な拉不十分で推論が入り独断に陮った点もある。十 勝平野地域は石油地質学的には未だ調查の緒についたば かりである。一番の問題は調査資料の充実である。特に (1)豊䪸地区と本別地区とを結ぶ地震探鉱を実施し, 地表 調查ては分らない上部層の不整合以下の含油層の構造を 発見し，併せてその発達状況を知り，堆積盆地の形状を 明らかにする事，(口)同様に札内・幕別両背斜系列の延長 部を調查し，構造の発見のみならず本地域全体の盆地の 規模を把握する要がある。(瑂序は凡ての基礎となるも のであるから，重点的地表調査を行いこれの充実を計 る。以上の事が望まれる。

\section{参 考 交 献}

1）岡村要蔵：北海道網走屈斜路地方地質調查報文, 鈗物調查報告, 20 号, p. 1 47, 1911.

2）大石三郎 - 渡辺武男: 然別沼図幅同説明書, 北海 道地質調查会報，第 1 号， 1933 .

3）根本忠筧・大石三郎・渡辺武男：帶広図幅同説明 書, 同上第 2 号, 1933 .

4）根本忠宽・佐々保雄：大樹図幅同説明書，同上第 3 号, 1933.

5）橋本 亘：带広周辺地留調查報告，帝石*，1955.

6）佐々保雄・阙崎由夫 - 吉田三郎：止若 $\mathrm{A}$ 班地賀 調查報告, 帝石, 1955 .

7）佐々保雄・佐藤誠司：止若 B 班, 帝石, 1955 .

8）佐々保婎・橋本 亘・吉田三郎・佐藤誠司・岡崎 由夫，他：带広盈地及びその周辺の地質（第 1 報） 第三系の 酋序 (要旨)，地質学雑誌， 61 巻， 718 号, 1955.

9）橋本 亘：十勝支厅管内の地質及び地下瘝源，十 勝綜合開発促進期成会, 1955 .

10）三谷勝利・小山内熙 - 橋本 亘: $1 / 5$ 万足寄太図 幅・同説明書，北海道開発庁，1958.

11）三谷勝利・橋本 亘・吉田 尚・織田精德： $1 / 5$ 万本別図幅・同説明書, 同上, 1959.

\footnotetext{
* 滀国石油株式会社社内報告 (未発表) 以下同 !
}

12）織田精徳・根本忠寛・植村 武：1/5 万 常室図 幅・同説明書，同上， 1958.

13）棚井敏雅：1/5 万音別図幅 - 同説明書, 同上, 1957.

14）佐々保雄：北海道止若附近新油街地，石技䄊， 7 巻, p. 558 561, 1939.

15）島田忠夫：北海道十勝国大樹附近油徴地予察調 查, 地質調査所月報, 4 卷, p. $541 \sim 543,1953$.

16）地筫調查所：日本鉱産誌 V-6，石油及び可燃性 天然ガス, 東京地学協会, 1957.

17) Wendlandt E. A. : Exploration Planning, edicated by J. D. Hann and L. W. Le Roy Subsurface Geology in Petroleum Exploration, Chapter 41, p. $815 \sim 858,1958$.

18）三士知芳：石油の移動についての考察，石技誌， 第 25 巻，第 4 号, p. 200 239, 1960.

19）石田義雄：地下に打ける石油の移動と油田構成の 経過について，同上，p. 240 249.

20）石井基裕：秋田の油田地筫につきて, 地筫学雅誌, 60 巻, p. $285 \sim 286$.

21）佐々保雄 - 根本忠寞 - 橋本 亘： $1 / 60$ 万北海道 地啠図幅説明書，科学技術連盟，1952.

22）橋本 亘, 他：北海道地質図（1６）説明書，北 海道地下資源調查所，p. $1 \sim 58 ， 1958$.

23）長尾唅一・三谷勝利：十勝周縁地域，天然力又鉱 床調查報告，北海道地下資源調笪資料，第 61 号， 1960.

24）日本地筫学会編：地層名辞典，A O , 1955 1959.

25）日本石炭協会北海道支部編：北海道炭田誌第 2 号 釧路炭田, 1953.

26）吉田三郎：十勝中川郡唺頃村上り Fortipecten takahashii 0 発見, 北海道地学会, p.21.

27）岡崎由夫：北海道東部池田層の地筧，同上， p. 1 $\sim 8$.

28）橋本 亘：北海道の地質 $[1] \sim[13]$ ，雑誌地下資 源，北海道鉱業振興協会，1 13 号，1958.6 1961.7.

29）佐及保推：北海道古第三系に関する問題，有孔虫, 6 号特集 (2) p. 1 22.

30）広沢 孝：十勝平野重力探鉱報告，帝石，1956.

31）带広䤃部重力探鉱報告, 石開*, 1957.

32）関東 墨：帶広重力探鉱報告(東部), 石開，1958.

33）：同上(西部), 1958.

34）正谷 清・林 良和・城戸秀夫：北海道应尾鄂豊 頃地表調査 $(ル-ト)$ 報告, 石開, 1957.

35）城戸秀夫：北海道中川郡高島調查(ルート) 報告, 石開, 1958.

36）林良和：北海道中川郡池田（ルート）報告, 石 開, 1958.

37）西沢量平・片平忠実：浦䗷調查報告，石開，1958,

38) 片平忠実: 北海道中川郡, 広尾郡生花苗(ルート) 報告，石開，1959.

39) 長坂 満: 北海道中川郡札内 $(ル ー ト)$ 調查報告, 石開, 1959 .

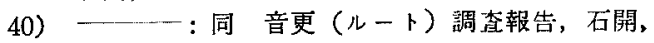

* 石油筫源開発株式会社社内埌告 (来発装) 以下同 
1960.

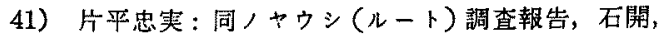
1960.

42）鬼塚 貞: 同粶内(ルート)調查報告, 石開，1960.

43）加藤精一郎：北海道広尾郡大樹調查報告, 石閆, 1960.

44）西島 進: 同当縁地表調查報笞, 石開， 1960 .

45）岩本寿一：北海道十勝微古生物調查報告, 石開, 1957.

46）大會 保: 北海道十勝国生花苗有孔虫調査報告, 石開, 1960 .

47）小村精一：同帶広珪藻調查報皆，石開，1960。

48）埧津益次郎：池田地震探鉱，石開，1959.

49）ㄴ... 带広地䈔挆鉱，石開，I960.

50）— : 荼別地繁探鉱，石開，1960,

51）酒匂絹俊 - 長谷川潔：1/5万十勝川図幅 - 同説明 書, 北海道開発庁, 1957.

52）橋本誠二: $1 / 5$ 万御影図幅 - 同説明書, 北海道地 下資源調督所, 1954 .

53）橋本誠二: $1 / 5$ 万 札内岳図幅 - 同説明薔, 同上, 1953.

54）長谷川潔・酒包純俊：1/5万神居岳図幅・同説明 書, 北海道発庁, 1958.

55）橋本誠二・鈴木守他：1/5万 楽古岳図幅・同説明 書, 同上, 1959.

56）猪木幸男・椝 光男：1/5万猿留図幅 - 闰説明 書，地留調查所， 1956.

57）小村精一：ダイアトムによる石狩，日高間の対比 (要旨)，石技誌， 24 巻， 4 号，p. 26，1959.

58）—：石狩郡珠藻 A 诽報告, 石開, 1958.

59）—: 静鹏 SK-1 号の珪藻化石報告, 石開, 1959.

60）小村精一・岩本寿一：勇払郡武鳥川・柽舞の微古生
物チェック，石開， 1959 .

61）小村精一：雨竜郡一の沢 SK-1 の珪菠化石埌告， 石開, 1959.

62）四：美葉牛 SK-1 0珪藻化石報告，石開， 1959.

63）—: 玲洽化石調查報告, 石開, 1959.

64）一：日萿珪莯化石調查報告，石開，1960.

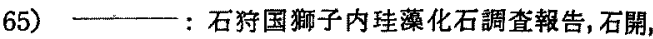
1960.

66）吾妻 稕 : 北部石狩低地带周辺の滰川層群，北海 道地筫要報, 39 号, p. 19 40, 1960.

67）長尾捨一・本島公司ほか：十勝平野天然ガス調查 報告，北海道地下盗源調 查資料，50 号，p.1 49, 1959.

68）島田忠夫：止若及び下代田の天然ガス予察報告， 地質調沓所月報, 4 巻, p. 655 .

69）本島公司-牧野登喜男・安国 昇・斎藤仁: 北 海道十勝国池田町字千代田附近の天然が ス, 石技 誌, 19 巻, $p, 141 \sim 145,1954$.

70) 竹田秀蔵：北部日本 (北海道) 新生代解釈試編， 鈴木醇教授䏇曆記念論文集， p. 490 502，1958.

71）藤江 力ほ加 5 名：新生代の堆積区とその变逼 (5) 一一北海道地域一一新生代の研究，24，25号, p. $51 \sim 58,1957$.

72）魚住 语 - 藤江 力: 北海道第三紀の地層対比, 同上, 26 号, p. $24 \sim 33,1958$.

73）藤江 力: 滝川 - 本別化石群と代表種 Fortipecten takahashii の分布，同上，30号，p. 28 39, 1959.

75）舟橋 三男・橋本誠二：日高带の地筫，地団研度 報， $6,1951$.

76）撟本 晋：北海道中生界研究最近の進步（要旨）, 地質学雑誌 60 巻, 1954 . 